Jpn. J. Oral Biol., 33 : 26-45, 1991.

\title{
腺様囊胞癌による基底膜タンパク質生合成の 免疫組織細胞化学的解析
}

\author{
程珺 \\ 長崎大学椟学部口腔病理学講座 (主任 : 岡邉治男教授)
}

〔受付：平成 2 年 9 月 12 日〕

\section{Biosynthesis and stromal accumulation of basement membrane molecules in adenoid cystic carcinoma : an immunohistochemical study}

\author{
Jun Cheng \\ Department of Pathology, Nagasaki University School of \\ Dentistry, 7-1 Sakamoto-machi, Nagasaki 852 \\ (Chief: Prof. Haruo Okabe) \\ [Accepted for publication: September 12, 1990]
} Key words : Adenoid cystic carcinoma / basement membranes / immunofluorescence / immunoperoxidase
technique / tissue culture

\begin{abstract}
Tissue samples from patients with adenoid cystic carcinoma (ACC) and those with adenocarcinoma (AC) of salivary gland origin were studied by immunohistochemical staining with specific antibodies to the four macromolecules that are present in normal basement membranes (BMs): type IV collagen, laminin, heparan sulfate proteoglycan and entactin. In ACC, the four proteins were immunolocalized in different types of extracellular matrix in the tumor, namely pseudocystic spaces, hyaline stroma, and around tumor cell nests. The staining intensity was enhanced by pretreatment with hyaluronidase. The tumor cells of ACC showed a tendency to proliferate with individual cells in contact with the $\mathrm{BM}$ and to infiltrate through BM-rich tissues such as peripheral nerves, blood vessels, and skeletal muscles. In contrast, only circumferential staining of tumor cell nests was obtained in AC. Immunostaining with antibodies to BM proteins seemed to be quite useful for differential diagnosis between these two carcinomas. We further intended to confirm that these stromal BM proteins were produced by the ACC parenchymal cells themselves. To this end, we used two cell lines, ACC2 and ACC 3 , established from human ACC tissues, and determined immunolocalization of the four basement membrane molecules and fibronectin in vitro. These proteins were shown to be immunolocalized in the cytoplasm and then in intercellular spaces, as the cells attach, spread, and grow. The results suggest that ACC cells produce BMs and fibronectin, and this basic nature is reflected in its histology and biological behaviour.
\end{abstract}

緒言

ヒト唾液腺に発生する腺様襄胞癌は，病理組織

（广 852）長崎市坂本町 7 番 1 号
学的には, 腫瘍胞巣内に多数の襄胞様構造を形成 するのが特徴である。この構造は節状構造とよば れ，二種類の細胞集簇単位からなることがしられ ている。第一に，その大部分をしめる単位構造は 間質偽霟胞である。この襄胞様構造は小型の筋上 
皮様細胞で形成され，剩胞腔は細胞外基質でみた されている。第二は腺管腔様構造で, 導管上皮様 細胞からなり，管腔内には唾液腺分泌物様好酸性 無構造物質が貯留している(1-6)。前者の偽呈胞は, 電顕的には，一層ないし多層の基底膜様構造で内 面をおおわれ，内腔に無構造の粘液物質とわずか の膠原線維の断片をいれており，著者らはこれは 腫瘍間質の特殊な変性像であることを 報告してき $た^{7-12)}$ 。しかし, この特徵的な偽輬胞内容物の性 状，とくにその構成タンパク質の詳細にはいまだ 不明な点がおおく，生化学的方法での解明がまた れていた。また, 腺様輁胞癌の臨床的特徵のうち, ゆるやかな経過, 末梢神経にそった進展 ${ }^{5)}$, リン パ行性より血行性の転移の 優位 ${ }^{6)}$ などは，きわめ て興味ある生物学的性格として, 注目されてき た。

そこで, 今回の研究では, この腫瘍の特異な組 織構筑と腫瘍細胞の生物学的性格を 理解すること を目的に，ふたつの実験をおこなった。第一の実 験として，IV型コラゲン, ラミニン，ヘパラン硫 酸プロテオグリカン, エンタクチンの四種の基底 膜物質に対する抗体をもちいて，この腫瘍の間質 を免疫組織化学的に検索した。その結果, 基底膜 物質が腫瘍間質に蓄積していることが判明し，腫 瘍細胞の基底膜親和性が本腫瘍の 基本的な生物学 的性格のひとつであることがあきらかになった。 また, この免疫染色の外科病理学的応用として, 腺癌と腺様震胞癌の 鑑別診断の 可能性を検討し た。

しかし，腺様輍胞癌の間質に豊富な基底膜物質 が腫瘍細胞自身によって産生されるのか，間質細 胞によるのかどうかは不明であるので，第二の実 験では，七卜唾液腺腺様襄胞癌由来の株細胞をも ちいて, 試験管内で腫瘍実質細胞による基底膜物 質の生合成を免疫細胞化学的に 証明することを計 画した。

\section{材料と方法}

\section{実験 I}

症例 : 免疫組織化学的染色に使用した 症例は, 大小唾液腺の腺様輷胞癌30例を, 上海第二医科大 学口腔医学院口腔病理学教室のファイルから 無作
為に選択した。腺様輁胞癌症例は, 病理組織学的 に, Tarpley $ら^{13)} と$ Perzin ら ${ }^{14)}$ の分類方法を参 考にして，ヘマトキシリン・エオジン (H. E.) 染 色標本によって, cribriform type (15例), tubular type ( 3 例), solid type ( 2 例), solid type with necrosis ( 2 例) と mixed type ( 9 例) の五型に 分類した。腺癌症例は, WHO 分類 $(1972)^{15)}$ の adenocarcinoma のうち, 特殊な分化傾向を有さ ない腫瘍 20 例を同ファイルより 選択し, tubuloductal type ( 9 例), solid type ( 4 例), mixed type ( 7 例) の三型に分類した。

抗体：本実験に使用した抗体は，四種類の基底 膜物質, IV型コラゲン，ラミニン (P1 fragment), ヘパラン硫酸プロテオグリカン，およびエンタク チンに対するウサギポリクローナル抗体である。 IV 型コラゲンは Kühn らの方法 ${ }^{16}$ によって，ヒト の胎盤から抽出し，ラミニン（P1 fragment）は Risteli \& Timpl の方法 ${ }^{17)}$ にしたがって, ヒトの 胎盤から精製し， ヘパラン硫酸プロテオグリカン とエンタクチンは Saku ら ${ }^{18,19 '}$ が，マウスのEHS 腫瘍から，それぞれ抽出精製したものである。抗 体はいずれも米国 Stanford 大学医学部病理学教 室 Furthmayr 教授研究室および長崎大学歯学部 口腔病理学教室で作製され，アフィニティカラム で精製された標品 ${ }^{201 を も ち い た 。 ~}$

免疫組織化学的染色 : 外科摘出材料を $10 \%$ フォ ルマリン固定したのち，パラフィン包埋し， $5 \mu \mathrm{m}$ パラフィン連続切片を作製した。タンパク質の非 特異吸着を阻止するために，脱パラフィンした切 片を $5 \%$ 脱脂粉乳 (雪印乳業) $/ \mathrm{PBS}$ (リン酸緩衝 生理食塩水) 液で $37^{\circ} \mathrm{C}, 30$ 分反応させた。ついで, Sternberger らの酵素抗体法 (PAP 法) ${ }^{211}$ によっ て免疫染色をおこなった。切片は一次抗体（10-50 $\mu \mathrm{g} / \mathrm{ml})$ で $4{ }^{\circ} \mathrm{C} ， 17$ 時間反応させ，ヤギ抗ウサギ IgG (1:100, Cappel Laboratories, Cochranville, PA, U. S. A.) とウサギ PAP (1: 100, Cappel Laboratories) でそれぞれ室温 1 時間反応 させた。同時に，もう一組の切片は Leivo らの 方法 ${ }^{22}$ にしたがって，300 I.U./ml ヒアルロニダ 一ゼ (ウシ精巣由来, 生化学工業) $/ 0.01 \mathrm{M}$ リン酸 緩衝液, $\mathrm{pH} 7.4$ で， $37^{\circ} \mathrm{C}, 30$ 分処理したのちに免 疫染色をおこなった。内因性ペルオキシダーゼの 
活性阻止のためには，切片を $0.3 \%$ 過酸化水素／ メタノールで，室温30分反応させた。対照実験で は，一次抗体のかわりに正常ウサギ IgGをもち いた。反応産物は $3,3^{\prime}$-ジアミノベンチジンで発 色させ，核染色はへマトキシリンでほどこした。

染色結果の評価：陽性の判定は，同一切片上の 正常組織，たとえば，血管内皮，血管平滑筋，骨 格筋, 末梢神経, 口腔粘膜上皮, 唾液腺導管, 腺 房などの基底膜の染色強度を参考にしておこなっ た。腺様囊胞癌では, 囊胞腔, 腺管腔, 胞巣周囲, 胞巣間質に, 腺癌では, 胞巣周囲に, それぞれ注 目して判定し, 各部位での陽性率をもとめた。

\section{実験 II}

細胞 : 細胞は28歳女性の口蓋小唾液腺および 49 歳男性の耳下腺に発生した腺様壤胞癌より通法に よってそれぞれ単離, 株化された二種の細胞系 :

ACC2, ACC3 をもちいた。これらの細胞株の性 格は，すでに， He らが報告している ${ }^{23)}$ 。本実験 は，これらの細胞株の150代から170代の継代でお こなった。細胞は15\%ウシ胎児血清，1％グルタ ミン, $50 \mu \mathrm{g} / \mathrm{m} l$ ストレプトマイシン, $50 \mathrm{I} . \mathrm{U} . / \mathrm{m} l$ ペニシリンをくわえた RPMI-1640 培地で, 加湿 した $5 \%$ 炭酸ガス環境下で培養した。

細胞増殖度の測定 : 細胞の増殖曲線は 重複培養 法 $^{24)}$ によってもとめた。培養開始細胞数は $3 \sim 5 \times$ $10^{4} / \mathrm{m} l$ の濃度で, $1.5 \mathrm{~m} l$ 密栓つきプラスチック チューブをもちいて， $37^{\circ} \mathrm{C}$ で培養をおこない， 24 時間ごとに細胞数を 3 列のチューブについて 測 定した。細胞外基質の細胞増殖への影響をみるた めに，基底膜関連タンパク質のひとつファイブロ ネクチンを培養チューブにコーティングして，細 胞数を同様に測定した。ファイブロネクチンは

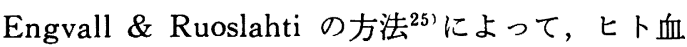
漿から精製した。0.05M トリス緩衝液（pH 7.4） で $30 \mu \mathrm{g} / \mathrm{m} l$ の濃度に希釈して， $4^{\circ} \mathrm{C} ， 24$ 時間コー ティングをおこなった。

免疫細胞化学的染色 : 培養細胞 $3 \times 10^{4}$ を $35 \mathrm{~mm}$ ペトリ皿にうえこみ，24時間ごとに，PLP 固定液 で, $4^{\circ} \mathrm{C}, 30$ 分固定し，0.2\%トライトン X-100で, $4^{\circ} \mathrm{C}, 20$ 分反応させて細胞膜透過性をたかめた。つ いで， $5 \%$ 脱脂粉乳 $/ \mathrm{PBS}$ で， $4^{\circ} \mathrm{C}, 17$ 時間反応さ せてタンパク質の非特異吸着を阻止したのち，間
接螢光抗体法によって染色した。抗体反応は一次 抗体，二次抗体ともに室温 1 時間抗こなった。同 一ペトリ皿をラバーセメントで 6 分割して同時に 多種の染色を進行させた。

抗体：一次抗体には，実験 I で使用した四種類 の抗体のほかに，ヒト血嶈ファイブロネクチンに 対するウサギ抗体をもちいた。このポリクローナ ル抗体は前述の精製ファイブロネクチンを抗原と して作製した。また，細胞形態を観察するために， ヒト足底角質ケラチンに対するウサギ抗体 ${ }^{5)}$ をむ ちいた。これらのポリクローナル抗体は長崎大学 歯学部口腔病理学教室で 調製されたアフィニティ カラム精製標品である。いずれも10 $50 \mu \mathrm{g} / \mathrm{ml}$ の 濃度で使用した。二次抗体には，ローダミン標識 ヤギ抗ウサギ IgG（1：50, Miles Scientific, Naperville, IL, U. S. A.) をもちいた。

ヌードマウス移植腫瘍 : 腫瘍細胞 ACC2, ACC3 をそれぞれ $3 \times 10^{6} / 0.1 \mathrm{ml}$ の濃度で $\mathrm{BALB} / \mathrm{c}$ $(\mathrm{nu} / \mathrm{nu})$ マウスの背部皮下に移植した。形成され た移植腫瘍を切除し， $95 \%$ タノールで $4{ }^{\circ} \mathrm{C}, 17$ 時間固定後, パラフィン包埋し, $5 \mu \mathrm{m}$ 連続切片 をえた。切片にはへマトキシリン・エオジン染色 のほか, トルイジンブルー染色, アルシアンブル 一染色, PAS 染色の特殊染色をほどこし, さら に, 前述の基底膜構成分子の免疫染色を PAP 法 でおこなった。

\section{結＼cjkstart果}

\section{実験 I}

免疫組織化学的染色: 腺様囊胞癌と腺癌組織内 の陽性反応の評価は，同一切片上の正常組織の基 底膜の陽性反応を確認しながらおこなった。正常 組織では，血管内皮細胞下の基底膜，血管平滑筋 および骨格筋の基底膜，末梢神経周膜および内膜 の基底膜, 口腔粘膜上皮下の基底膜, 唾液腺腺房 および導管の基底膜に注目した。腺様露胞癌では, 偽囊胞内と腫瘍胞巣周囲に, 腺癌では腫瘍胞巣周 囲にそれぞれ注目して，基底膜タンパク質別に， 陽性を呈した症例を算定し，陽性反応率とした。 ヒアルロニダーゼ処理群と同無処理群の結果の比 較は Table 1 にしめした。症例数の不同は, 各 組織がかならずしもすべての組織切片上に存在し 
Table 1 Immunostaining for basement membrane proteins before and after enzymatic treatment

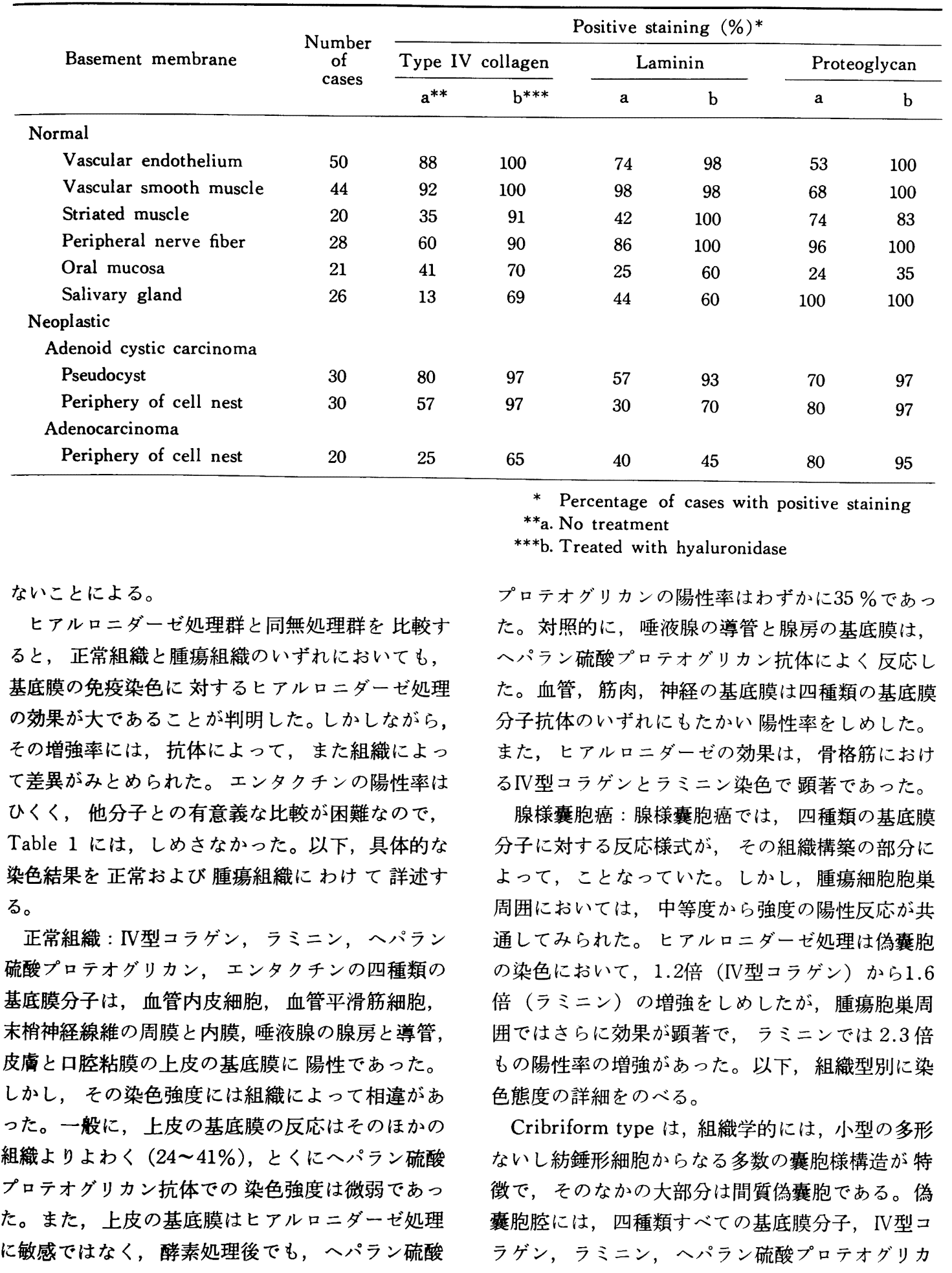




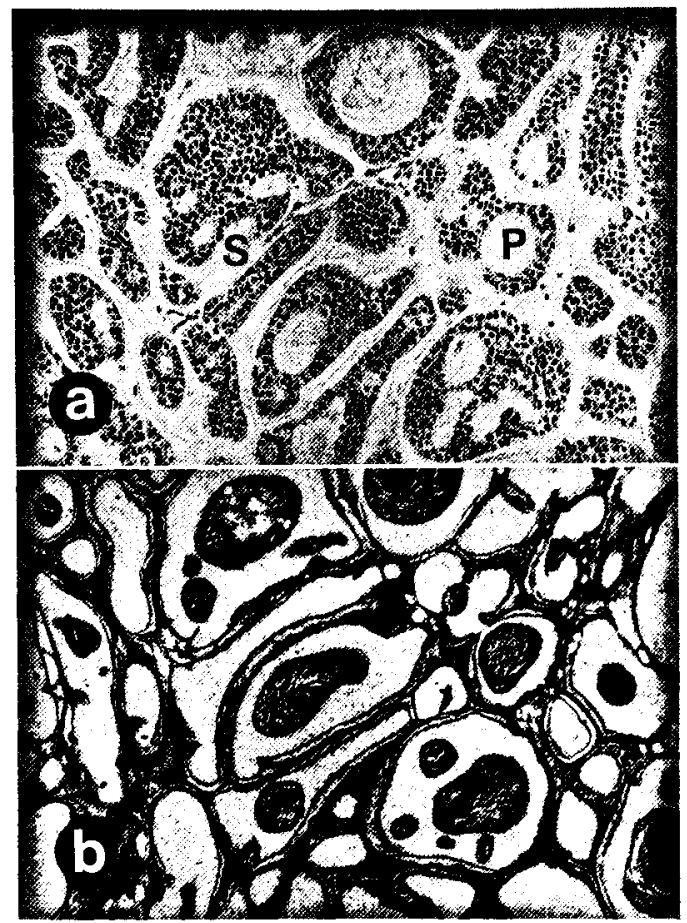

Fig. 1 Cribriform type of adenoid cystic carcinoma. a) Hematoxylin and eosin stain. b) Immunoperoxidase stain for heparan sulfate proteoglycan. Counterstain with hematoxylin. ( $\times 135)$ Pseudocysts (p), hyaline stroma ( $s$ ) and peripheral zone of tumor cell nests are strongly labeled.

ンエエンタクチンの陽性反心がみられた。偽哓胞 腔内の染色はぴまん性で，微細線維状，格子様, ないし点状を呈した。偽襄胞周縁はとくにつよい

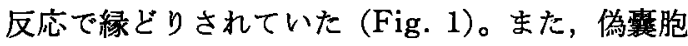
によって同一抗体でも染色強度がことなってい た。腫瘍細胞胞巣間の間質には, 免疫染色パタン のことなる二種類の部分が存在した。第一は， H. E. 染色では，細胞のきわめてすくない硝子様のも ので，基底膜分子の免疫染色では，つよく均質な 反応を呈した（Fig. 1)。第二は，H．E．標本で は，線維性の間質とみなされるもので，前者より 細胞密度はたかい。腫瘍細胞胞巣周囲の基底膜は 各抗体で陽性であったが，その外側に位置するこ の型の間質には，IV型コラゲン， ラミニン, エン タクチンの各染色はみられなかったが， ヘパラン 硫酸プロテオグリカン染色だけは，びまん性かつ

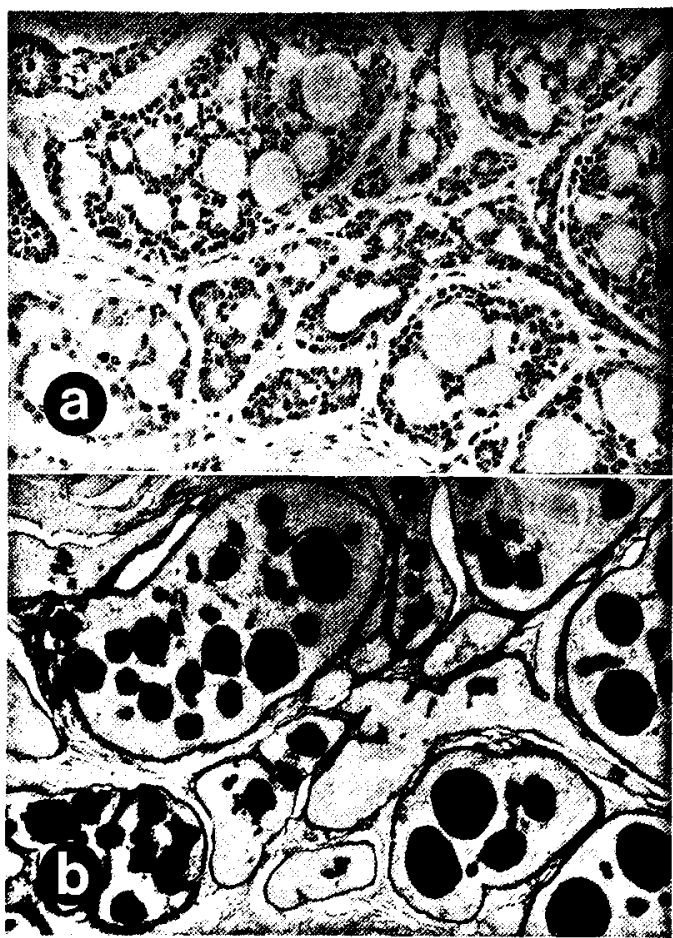

Fig. 2 Cribriform type of adenoid cystic carcinoma. a) Hematoxylin and eosin stain. b) Immunoperoxidase stain for heparan sulfate proteoglycan. Counterstain with hematoxylin. $(\times 178)$ In addition to strong staining of periphery of tumor cell nests, interstitial fibrous tissue is positive.

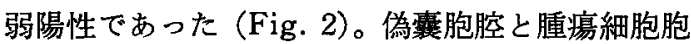
巣間質との交通はしばしば観察され，また，硝子 様間質と索状腫瘍細胞胞巣とが交互に配列し，特 徵的な唐草模様を呈した（Fig. 3)。

Tubular type では，立方形ないし多角形腫煬 細胞からなる導管様構造が特徵的であったが，充 実性ないし索状胞巣もみとめられた。四種類の基 底膜分子の免疫染色では，導管周囲は強く反応し たが，導管様腔内には，陽性反応がみられなかっ た (Fig. 4)。H. E. 染色によって tubular type に分類された症例のなかには，あたかも導管状を 呈する，篩状構造をとらない単一の偽謇胞が小型 胞巣内に, 形成されているむのがるくをれていた。 これらの症例では免疫染色後, 腔内の基底膜分子 陽性によって，偽囊胞の存在があきらかにされた (Fig. 5)。 


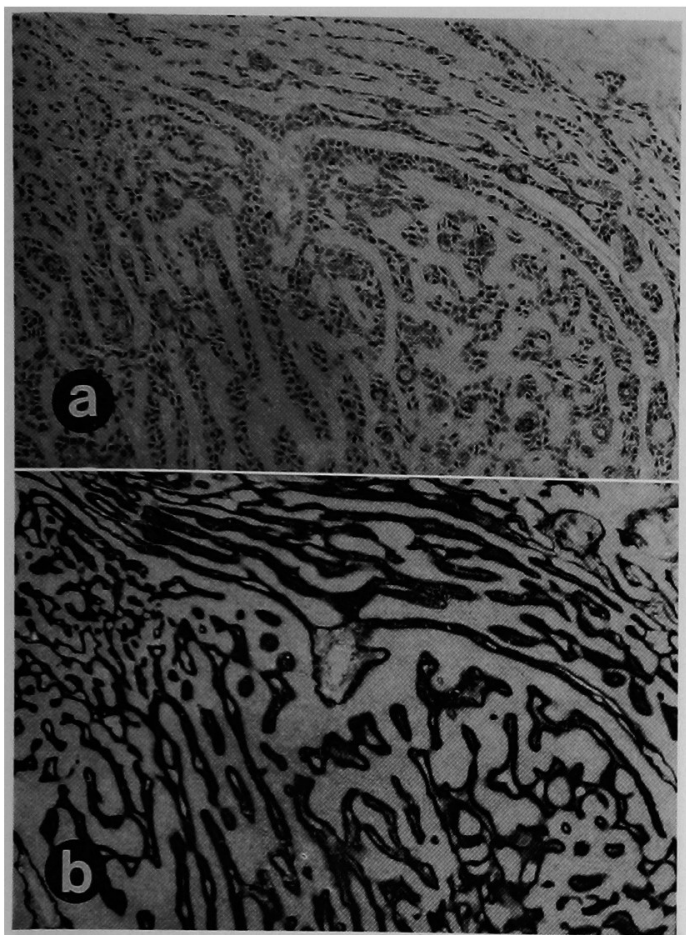

Fig. 3 Hyaline stroma of adenoid cystic carcinoma. a) Hematoxylin and eosin stain. b) Immunoperoxidase stain for type IV collagen. Counterstain with hematoxylin. (x135) Arabesque-patterned stroma, continuous with pseudocysts, is strongly positive for type IV collagen.

Solid type では, シート状に増殖した小型多角 形腫瘍細胞からなる充実性胞巣とせまい線維性の 間質がみられた。H．E．染色では不明瞭な多数の 小震胞が，免疫染色で基底膜分子に対する抗体で そめだされ，一見，充実性の腫瘍胞巣内にも，広範 囲な間質の陥入のあることがわかった（Fig. 6)。

Solid type with necrosis では, 小型の未分化 な腫瘍細胞からなる胞巣が類円形を呈し, 線維性 間質によってとりかこまれていた。各腫瘍胞巣は 中心壊死巣をともなっていた。H. E. 染色では認 識困難であった米粒状細胞外基質が，四種類の基 底膜分子の免疫染色で強陽性反応をしめし, この 組織型を特徴つけた。また，腫瘍細胞胞巣周囲も 陽性反応を呈した（Fig. 7)。

腺様㘊胞癌の末梢神経侵襲はよくしられている が, 基底膜免疫染色では, 神経周膜, 神経内膜に

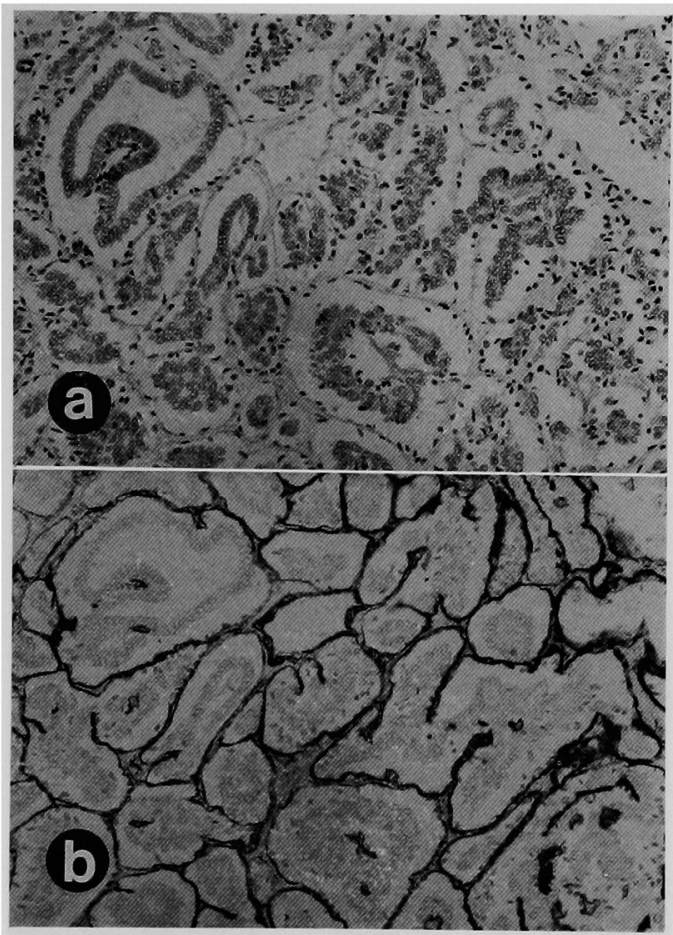

Fig. 4 Tubular type of adenoid cystic carcinoma. a) Hematoxylin and eosin stain. b) Immunoperoxidase stain for type IV collagen. Counterstain with hematoxylin. ( $\times 178)$ Periphery of ductal structures stain positively in a linear fashion, while luminal contents do not.

IV型コラゲン，ラミニン，ヘパラン硫酸プロテオ グリカン，エンタクチンの陽性をみとめた。腫瘍 細胞が神経周膜に接着し，しだいに内膜へと浸潤 していく様子がみられたが，浸潤してきた腫瘍細 胞自身の胞巣周囲にも，各基底膜分子陽性反応が みられた (Fig. 8)。同様の所見は, 基底膜の豊富 な血管壁 (Fig. 9) や骨格筋 (Fig. 10) にもみら れることが，この免疫染色であきらかにされた。

腺癌：腺癌は，H.E. 染色では, tubulo-ductal type, solid type と mixed type に分類されたが, 基底膜分子の免疫染色による染色パタンはいずれ の組織型でも単調で，腫瘍細胞胞巣周囲に陽性反 応がみとめられるのみであった。胞巣内に陽性反 応はみられなかった (Fig. 11)。ヒアルロニダー ゼ処理によって，IV型コラゲンの場合，2.6倍増強 の結果がえられた。しかし，ラミニンとIV型コラ 


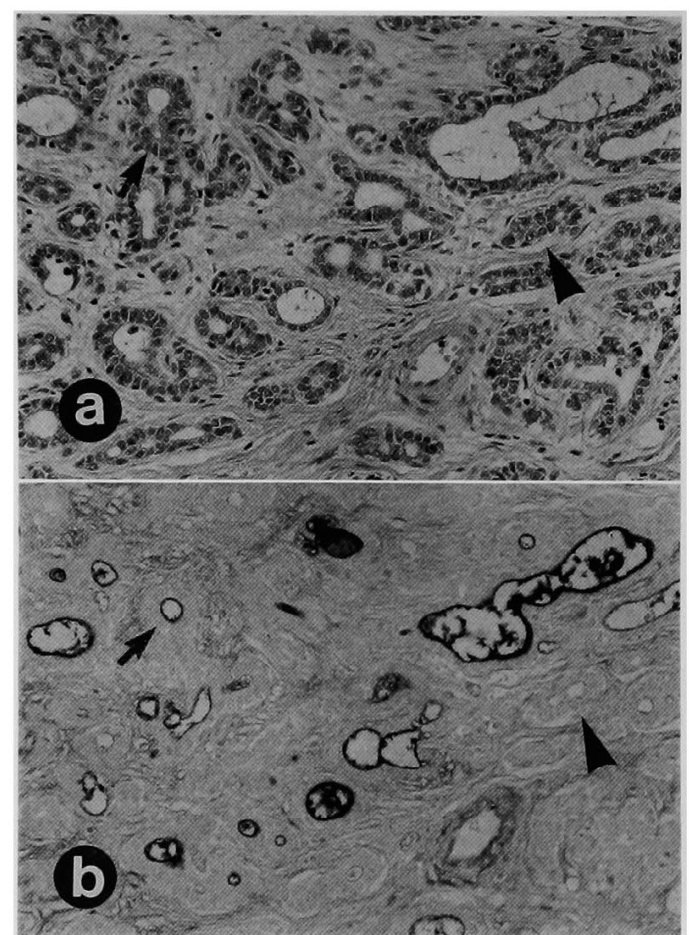

Fig. 5 Tubular type of adenoid cystic carcinoma. a) Hematoxylin and eosin stain. b) Immunoperoxidase stain for heparan sulfate proteoglycan. Counterstain with hematoxylin. $(\times 178)$ Small pseudocysts (arrow) are positive for proteoglycan, whereas true ductal structures (arrowhead) are not.

ゲンの 最終的な 陽性率は ヘパラン 硫酸 プロテオ グリカンのそれほどたかくならなかった（Table 1)。

\section{実験 II.}

移植腫瘍：ヌードマウス皮下に移植した ACC2 および ACC3 細胞は, 2〜 4 週後に, 直径 $5 \sim 20$ $\mathrm{mm}$ の腫瘍を形成した。形成された腫瘍は，滑沢 な線維組織様被膜でおおわれており，周囲皮下組 織から容易に剝離できた（Fig. 12）。腫瘍組織の 光顕的観察の結果, トルイジンブルー, アルシア ンブルー, および PAS 陽性をしめす偽營胞の形 成がみとめられ，腺様囊胞癌の性格，すなわち， 偽霓胞形成能を保持した細胞であることが 確認さ れた。偽豪胞腔内，および腫瘍細胞間隙には，四

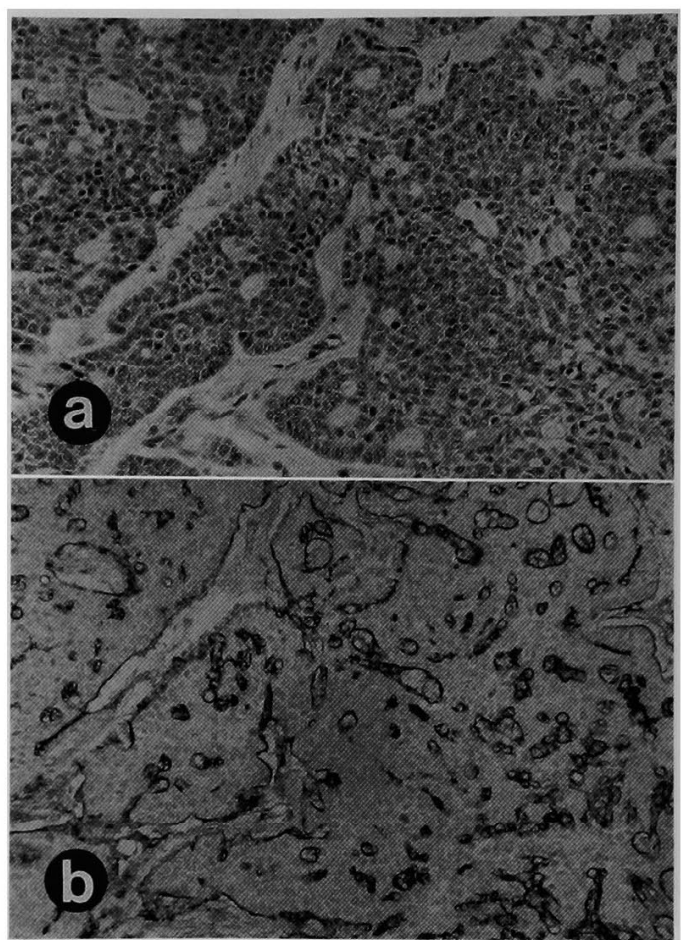

Fig. 6 Solid type of adenoid cystic carcinoma. a) Hematoxylin and eosin stain. b) Immunoperoxidase stain for type IV collagen. Counterstain with hematoxylin. $(\times 178)$ Immunostaining reveals numerous small pseudocysts within nests of tumor cells, while these pseudocysts are not discernible in hematoxylin and eosin stained sections.

種の基底膜分子とファイブロネクチンが免疫組織 化学的に証明された (Fig. 13)。ACC2 および ACC3 のあいだに明瞭な相違はなかった。以下の 実験においても，二種の細胞系でえられた 結果は 同様であった。

細胞増殖度 : Fig. 14 にしめすように, 重複培 養法によって測定した細胞堌殖曲線から， 細胞増 殖の doubling time は約36時間であった。継代後 4〜 5 日から，カーブのたちあがりがみられ，9 日目で細胞数は 15 倍の $4.5 \times 10^{5}$ までふえて，その 後, 減少した。培養チューブにファイブロネクチ ンをコーティングした場合, その doubling time は，無処理群の $1 / 2$ 以下の約16時間で，4 日目以 降のたちあがりも急勾配で，9 日目には，20倍の 


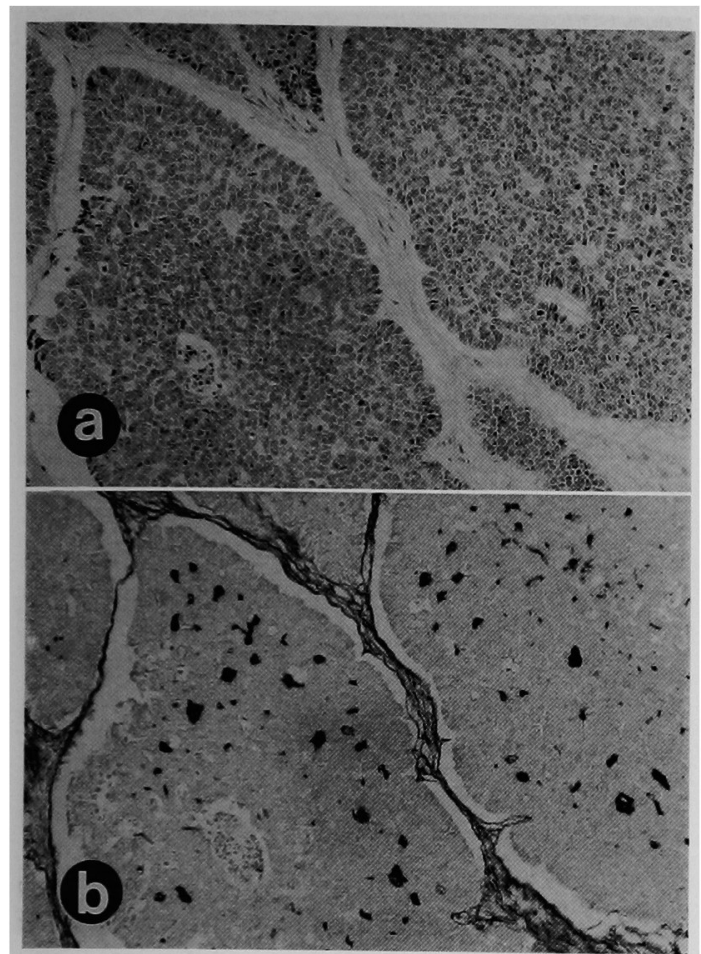

Fig. 7 Solid type with necrosis of adenoid cystic carcinoma. a) Hematoxylin and eosin stain. b) Immunoperoxidase stain for laminin. Counterstain with hematoxylin. ( $\times 135)$ Rice grain-shaped staining is characteristic of this type. Periphery of tumor cell nests is also positive.

細胞数まで増殖した。しかし，10日以降，細胞数 が減少するというパタンは，無処理群と同様であ った。すなわち, ファイブロネクチンの存在下で, 細胞はよく増殖することが判明した。さらに，フ ラスコに培養した細胞に，ケラチン免疫染色をほ どこして観察すると， 細胞形態が明瞭にしめされ た。ファイブロネクチンのコーティングされたフ ラスコでは， 細胞の伸展がいちじるしく，核周囲 の束状の線維束や, 細胞辺縁の微細な線維構造が 観察できた（Fig. 15b）のに対して，コーティン グのない場合，個々のケラチン線維の観察は困難 なことがおおかった（Fig. 15a)。

免疫細胞化学的染色 : 螢光抗体法による 免疫細 胞化学的染色の結果からは, ACC2, ACC3 細胞 が，いずれも基底膜構成分子のIV型コラゲン，ラ

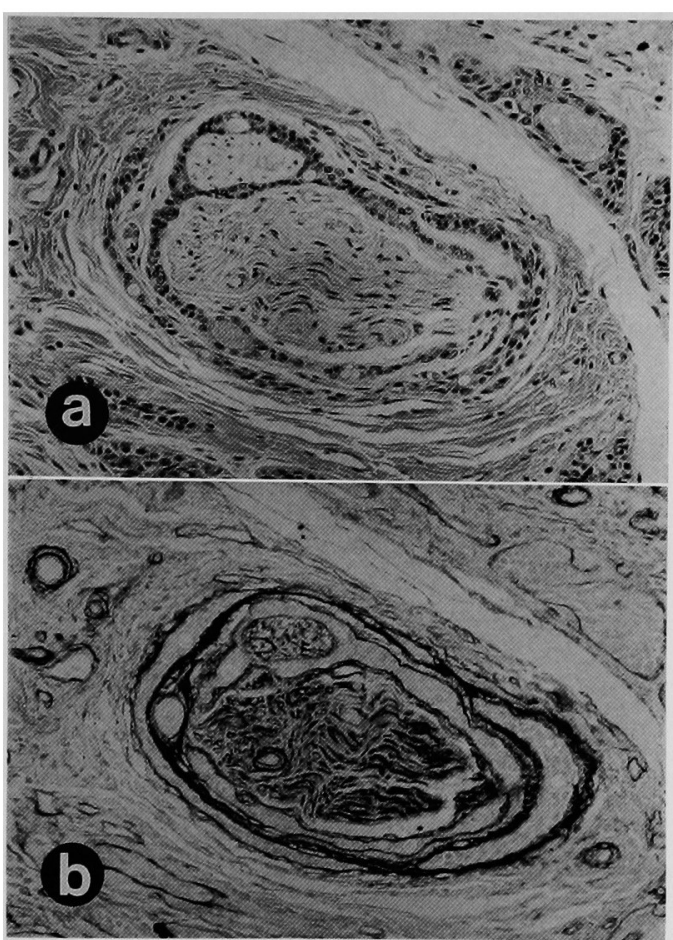

Fig. 8 Perineural invasion of adenoid cystic carcinoma. a) Hematoxylin and eosin stain. b) Immunoperoxidase stain for type IV collagen. Counterstain with hematoxylin. $(\times 178)$ Perineurium, endoneurium and periphery of invading tumor cell nests show positive staining.

ミニン，ヘパラン硫酸プロテオグリカン，エンタ クチンと，基底膜に関連した分子ファイブロネク チンを生合成することが示唆された。すなわち， 継代後, まず, 細胞質内のびまん性顆粒状の局在, つついて核周囲に局在の濃縮, その後, 細胞間に 点状から団塊状，さらには網状の沈着がみられた。 これらの細胞外基質成分の生合成と細胞内輸送 は，各タンパク質によって時期がことなり，細胞 増殖の進行と関連して，おこなわれているようで あった。以下に, 各タンパク質について, その詳 細をのべる。

IV 型コラゲン：IV型コラゲンの免疫染色では, 継代後 1 日目, 細胞質内には, びまん性, 微細顆 粒状の螢光がみられ (Fig. 16a)，2 日目から 4 日 目にかけて，細胞質内の陽性反応物のおおきさと 


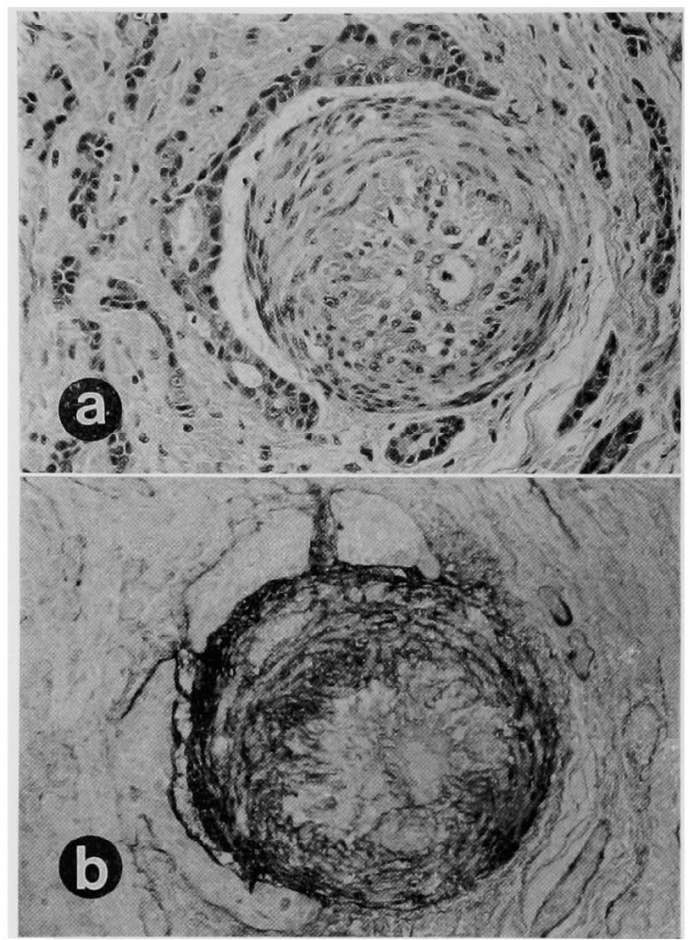

Fig. 9 Vascular invasion of adenoid cystic carcinoma. a) Hematoxylin and eosin stain. b) Immunoperoxidase stain for heparan sulfate proteoglycan. Counterstain with hematoxylin. $(\times 230)$ Basement membranes in hypertrophic arterial wall and of periphery of groups of invading tumor cells are positive.

数が増大寸るのが観察された (Fig. 16b)。これら の螢光シグナルは小胞体におけるIV型コラゲンの 局在と解釈し, 以下, 小胞体パタンとよぶことにす る。継代後 5 日目, 六部分の細胞の細胞質内の陽 性反応がいっせいに核周囲に集中し（Fig. 16c）, ゴルジ装置におけるその局在と解釈した。以下, この螢光反応をゴルジパタンとよぶことにする。 継代後 6 日目からは，細胞間隙に点状ないし線状 の陽性反応物 (Fig. 16d), さらに細胞表面に, 網状の陽性反応物（Fig. 16e）がみとめられた。 細胞外沈着が開始寸ると, 細胞内の螢光は微弱化 し，その後，ふたたび，小胞体パタン，つついて ゴルジパタンがあらわれた。しかし，6日目以降 細胞外沈着をしめす螢光は減弱せず，持続した。

ラミニン：ラミニンの免疫螢光染色では, 上述

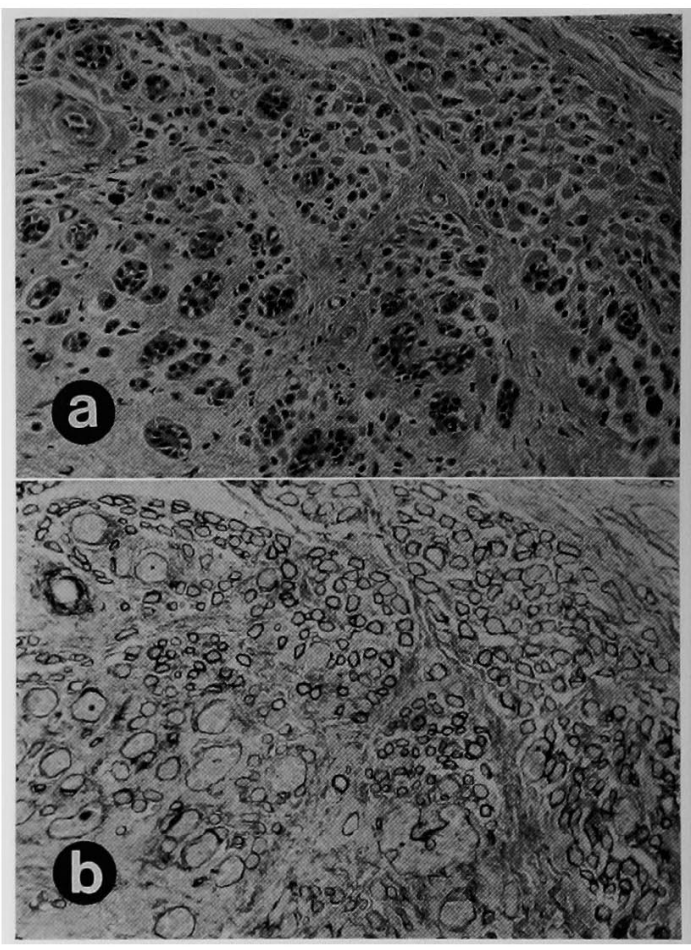

Fig. 10 Muscular invasion of adenoid cystic carcinoma. a) Hematoxylin and eosin stain. b) Immunoperoxidase stain for type IV collagen. Counterstain with hematoxylin. $(\times 178)$ Tumor cells infiltration replaces skeletal muscle fibers.

のIV型コラゲンの染色と同様, 継代後 1 日目から, 細胞質内には，小胞体パタンとみなされるびょん 性顆粒状の陽性反応が出現し，つづいてその増強 がみられた (Fig. 16f)。とくに細胞辺縁で䖝光強 度のつよい大型顆粒状のシグナルをみとめた。し かし，ゴルジパタンは，IV型コラゲンより一日は やく, 継代後 4 日目にみられ，5 日目には，核周辺 の顆粒状の螢光が増強した (Fig. 16g)。細胞間の 点状ないし線状の陽性反応は, IV 型コラゲン同様, 継代後 6 日目でみとめられた。さらに, 細胞表面 には，網状の陽性反応物がみられた (Fig. 16h)。 8 日目以降, 小胞体パタン, ゴルジパタンもくり かえして出現した。

ヘパラン硫酸プロテオグリカン：ヘパラン硫酸 プロテオグリカンの免疫螢光染色では, IV 型コラ 


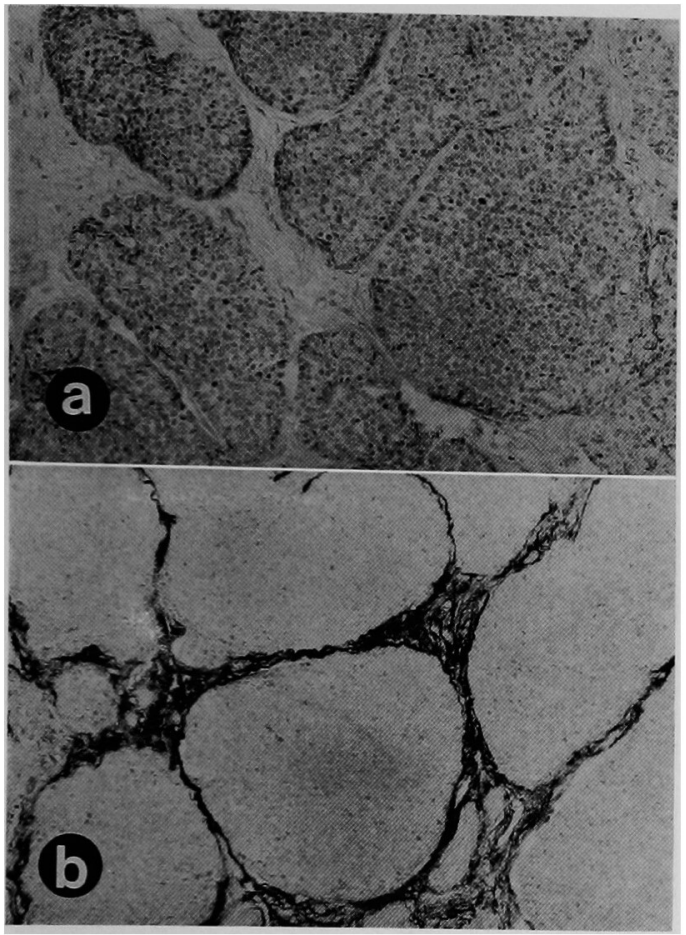

Fig. 11 Solid type of adenocarcinoma. a) Hematoxylin and eosin stain. b) Immunoperoxidase stain with type IV collagen. Counterstain with hematoxylin. $(\times 135)$ Only periphery of tumor cell nests are stained. There is no positive reaction within these groups of tumor cells.

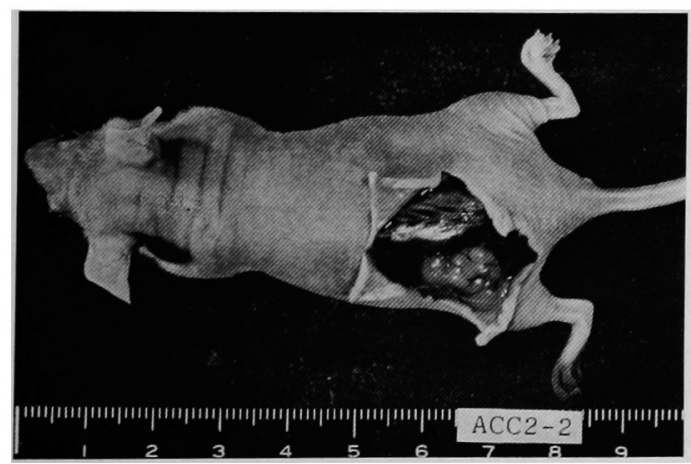

Fig. 12 Transplanted tumor (ACC2) in the back of a BALB/c (nu/nu) mouse. A well encapsulated tumor is located in the subcutaneous layer.
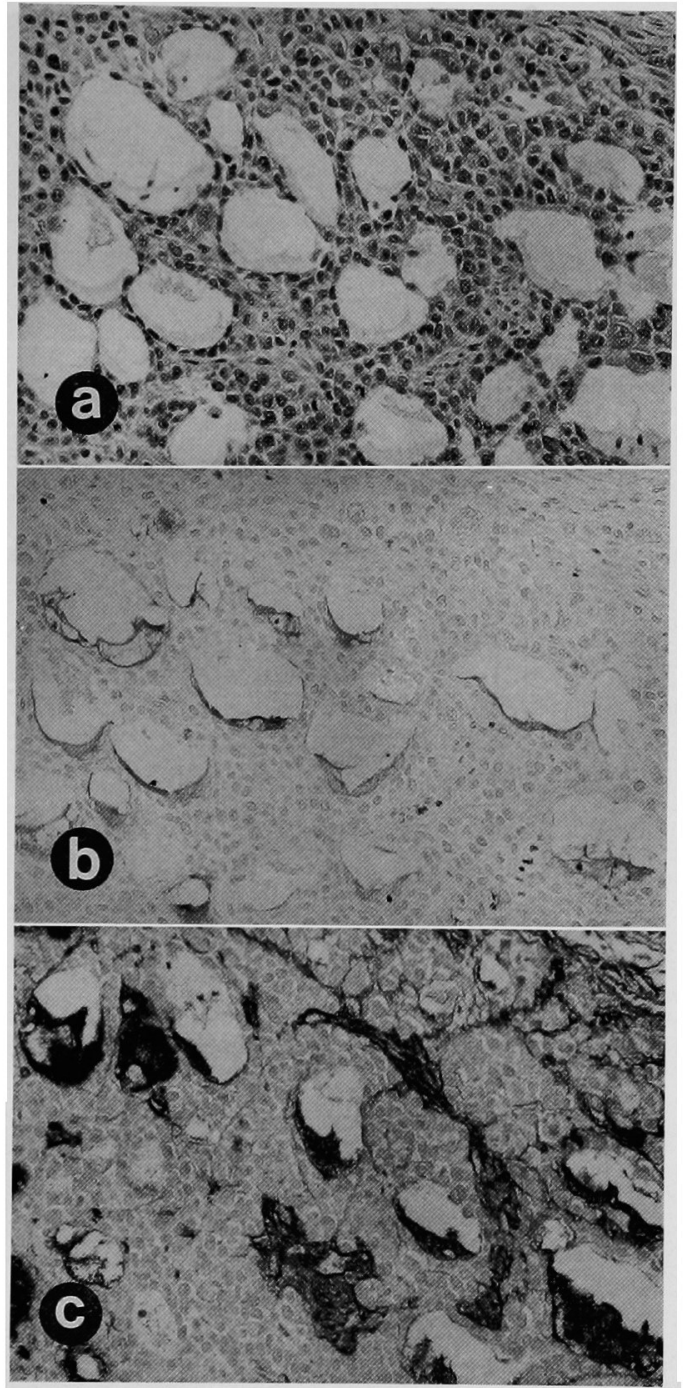

Fig. 13 Histology of transplanted tumor, a) Hematoxylin and eosin stain. b) Alcian blue ( $\mathrm{pH} \mathrm{2.5)} \mathrm{stain.} \mathrm{Counterstain} \mathrm{with}$ nuclear fast red. Formation of pseudocystic structures is obvious in the tumor tissues. c) Immunoperoxidase stain for heparan sulfate proteoglycan. Counterstain with hematoxylin. $(\times 178)$ Pseudocystic spaces stain positively for Alcian blue and basement membrane molecules.

ゲン染色の結果にもっとも類似して，細胞質内の びまん性で顆粒状の小胞体パタンが 継代後 1 日目 で出現し（Fig. 16i）, その後増強したが, 継代後 5 日目には，ゴルジパタンが出現した (Fig. 16j)。 


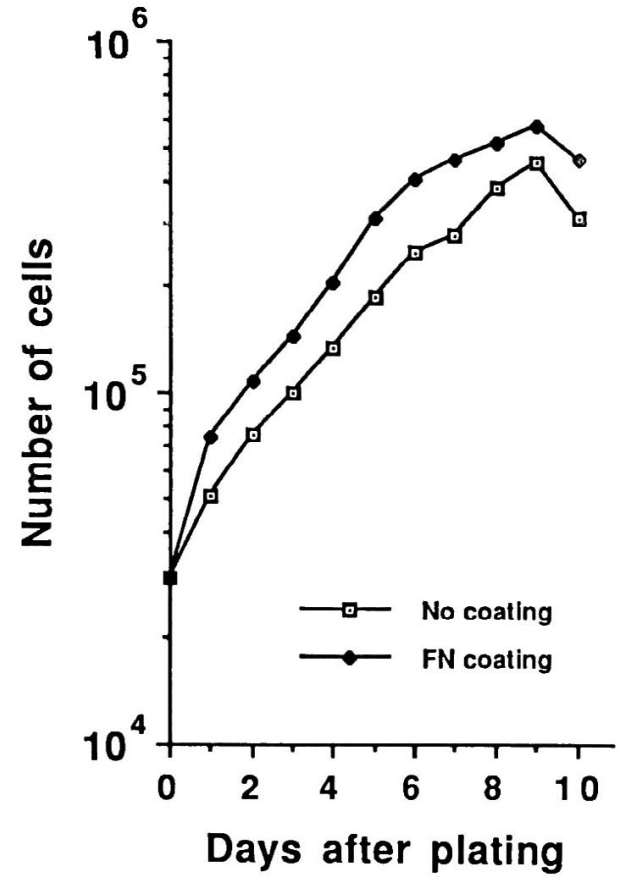

Fig. 14 Growth curve of ACC3 cells with ( $\square$ or without $(\cdot \overrightarrow{\cdot)}$ the presence of fibronectin, measured by replicated culture method. ACC 3 cells were plated in plastic tubes at cell concentration of $3 \times 10^{4}$ in $1 \mathrm{ml}$ complete medium and fed every two days with fresh medium. Another set of plastic tubes were precoated with fibronectin at concentration of $30 \mu \mathrm{g} / \mathrm{ml}$ for overnight at $4^{\circ} \mathrm{C}$ before plating cells. Doubling time of proliferation is about 36 hours in uncoated tubes, and about 16 hours in coated tubes.

翌6 日目からは，細胞内の螢光が減弱し，細胞間 隙の点状, 線状の反応物, ついで団塊状, 網状の 細胞外沈着物がみとめられ (Fig. 16k)，9 日目以 降には，細胞外沈着にくわえて，ふたたび，小胞 体パタンとゴルジパタンもみられた。

エンタクチン：エンタクチンの免疫螢光染色で は, 継代後, 1 日目から 5 日目までには, 細胞質 内の陽性は，ほとんど小胞体パタンでしかみとめ られなかった (Fig. 161)。ただ，この間，ごく小 数の細胞ではゴルジパタンと解釈できる螢光がみ られた (Fig. 16m)。しかし, 前述の三種のタン パク質のように培養細胞がいっせいにゴルジパタ

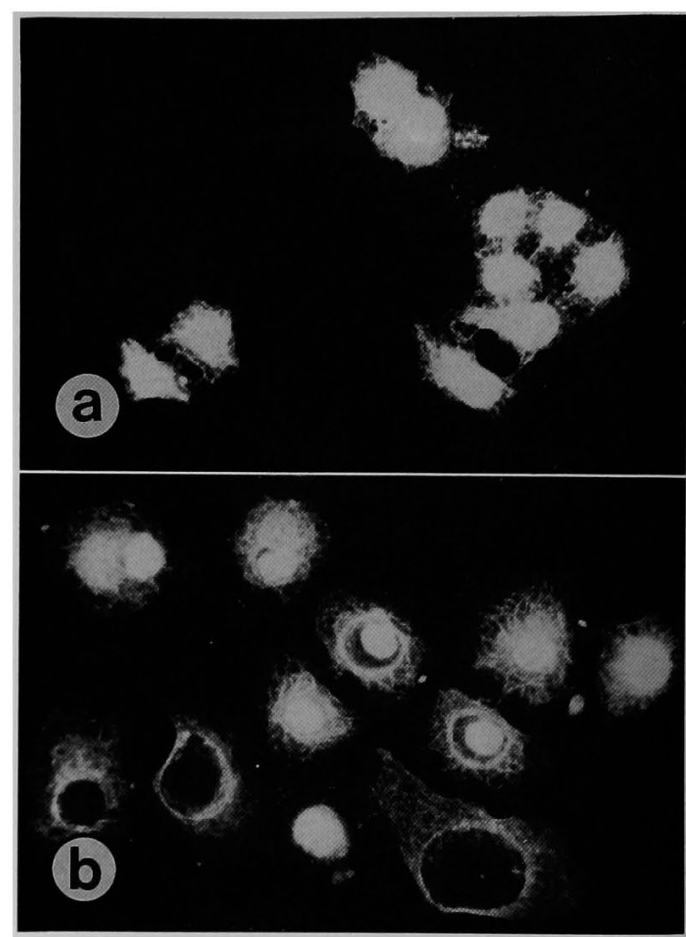

Fig. 15 Immunofluorescence stain of $\mathrm{ACC} 2$ cells for keratin, with b) and without a) fibronectin precoating. Two days after plating. $(\times 270)$ The cells spread much more on fibronectin.

ンをしめすような所見はえられなかった。細胞間 と細胞表面の沈着は, やはり継代後 6 日目からみ とめられたものの，大部分は点状と線状の沈着で あった (Fig. 16n)。螢光強度もよわく, その量も すくなかった。また, 細胞外沈着の開始後は, 細 胞質内の小胞体パタン，ゴルジパタンがほとんど みとめられなかった。

$$
\text { ファイブロネクチン：ファイブロネクチンの免 }
$$
疫螢光染色結果は, 前述の四種類の基底膜分子の それとはややことなり，小胞体パタンが一日おく れて, 継代後 2 日目に出現し, 螢光の顆粒がやや おおきく，また，多数みられた（Fig. 16o)。継代 後 6 日目から，ほかのタンパク質とおなじく，細 胞間と細胞外の 沈着があらわれたが，細胞表面 の網状の陽性反応物がきわめて多量にみられた (Fig. 16q)。細胞外沈着の開始まえには,ゴルジパ タンが明瞭ではなかったが, 継代後 8 日目以降に, きわめて小数の 細胞でゴルジパタンがみいだされ 


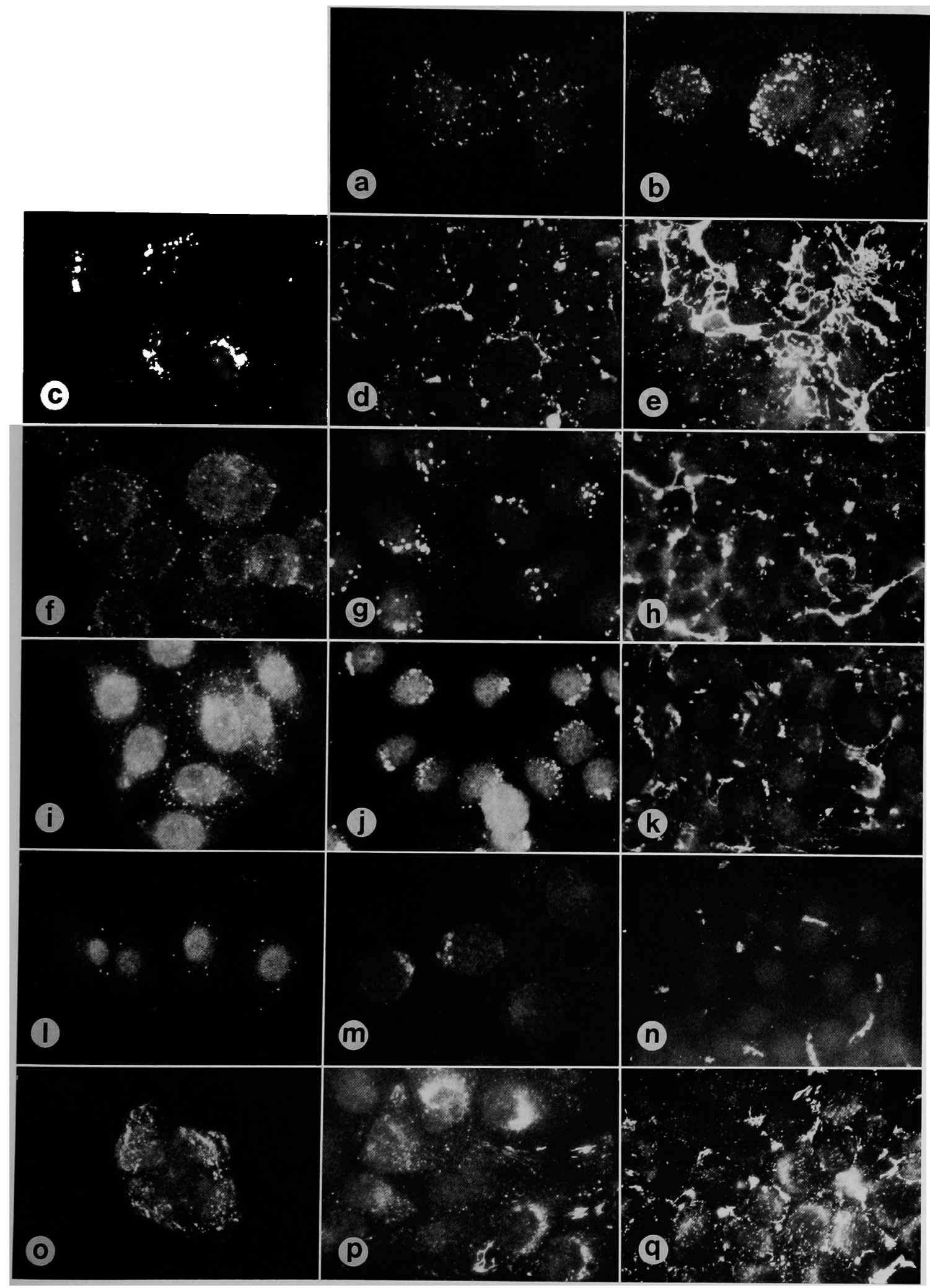


た (Fig. 16p)。

以上の螢光抗体法による五種のタンパク質の生 合成, 分泌過程の追跡結果を, Fig. 17 のように まとめた。小胞体パタンは, IV型コラゲン，ラミ ニン, ヘパラン硫酸プロテオグリカン, エンタク チン，とファイブロネクチンのすべてで確認でき たが，ファイブロネクチンでは，その出現が1日 おくれた。ゴルジパタンの出現は，ラミニンが 1 日先行し, IV 型コラゲン, ヘパラン硫酸プロテオ グリカンとともに多数の細胞で明瞭に 確認できた が，エンタクチンとファイブロネクチンでは不明 瞭であった。 6 日目ないし 7 日目以降の細胞外沈 着の出現と, 細胞内反応の減弱は相関していた。 細胞外沈着後, ふたたび小胞体パタン, ゴルジパ タンが出現する所見は, IV型コラゲン, ラミニン, ヘパラン硫酸プロテオグリカンで共通であった。

\section{考察}

基底膜は上皮細胞，内皮細胞，筋肉細胞などの 細胞と結合組織をへだてる膜状の 細胞外基質で, 細胞の接着, 物質の濾過のほか, 細胞の分化生長 に関与している。基底膜を構成する物質として, 現在までにすくなくとも四種のタンパク質 : IV型

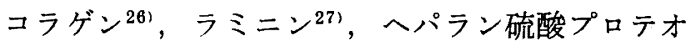
グリカン ${ }^{28)}$ とエンタクチン ${ }^{29}$ がしられる。しかし, これらの分子相互の結合様式，さらに，それらの 基底膜構築への役割は，いまだ，明確にされてい ない。

腺様霊胞癌の電子顕微鏡的観察によって，その 大部分の露胞様構造は, 細胞外基質の陥入による 間質の孤立化であることがわかっていた ${ }^{30)}$ 。した がって，この構造は，液状物の貯留による真の霟 胞と区別する意味で，偽露胞とよばれてきたわけ だが，この偽襄胞が多層化した基底膜様の構造物

Fig. 16 Immunofluorescence stain of ACC3 cells for type IV collagen (a-e), laminin (f-h), heparan sulfate proteoglycan (i-k), entactin (l-n), fibronectin (o-q).

a) One day after plating. Even and punctate intracellular staining suggests type $\mathrm{V}$ collagen localization in endoplasmic reticulum (ER). ( $\times 540)$

b) Two days after plating. Intracellular staining of ER pattern is noticeably enhanced. $(\times 540)$

c) Five days after plating. Enriched focal paranuclear staining suggests type IV collagen localization in Golgi apparatus. $(\times 540)$

d) Six days after plating. The cells are nearly confluent. Granular and thread-like extracellular aggregations of immunofluorescence for type $\mathrm{IV}$ collagen is observed, while intracellula rstaining is decreased. $(\times 540)$

e) Eight days after plating. The cells are in confluency. Thick network of immunofluorescence suggests extracellular deposition of type IV collagen. $(\times 540)$

f) Two days after plating. Diffuse intracellular staining of ER pattern for laminin. $(\times 540)$

g) Four days after plating. Paranuclear staining of Golgi pattern for laminin. $(\times 540)$

h) Nine days after plating. Extracellular deposition of laminin is found in coarse granular or thick thread-like fashion. $(\times 540)$

i) One day after plating. Fine and diffuse intracellular staining of ER pattern for heparan sulfate proteoglycan $(\times 540)$

j) Five days after plating. Golgi pattern staining for heparan sulfate proteoglycan. $(\times 540)$

k) Nine days after plating. Thread-like network of immunofluorescence for heparan sulfate proteoglycan in extracellular space. $(\times 540)$

1) One day after plating. Intracellular ER pattern staining for entactin. $(\times 540)$

m) Two days after plating. Paranuclear stainig of Golgi pattern for entactin is found only in a small number of cells. $(\times 540)$

n) Seven days after plating. Extracellular deposition of entactin. $(\times 540)$

o) Two days after plating. Intracellular ER pattern staining for fibronectin. $(\times 540)$

p) Seven days after plating. After extracellular deposition appears. Both Golgi and ER pattern stainings for fibronectin are found in a small number of cells. $(\times 540)$

q) Eight days after plating. Network of extracellular aggregation of immunofluorescence for fibronectin. $(\times 540)$ 

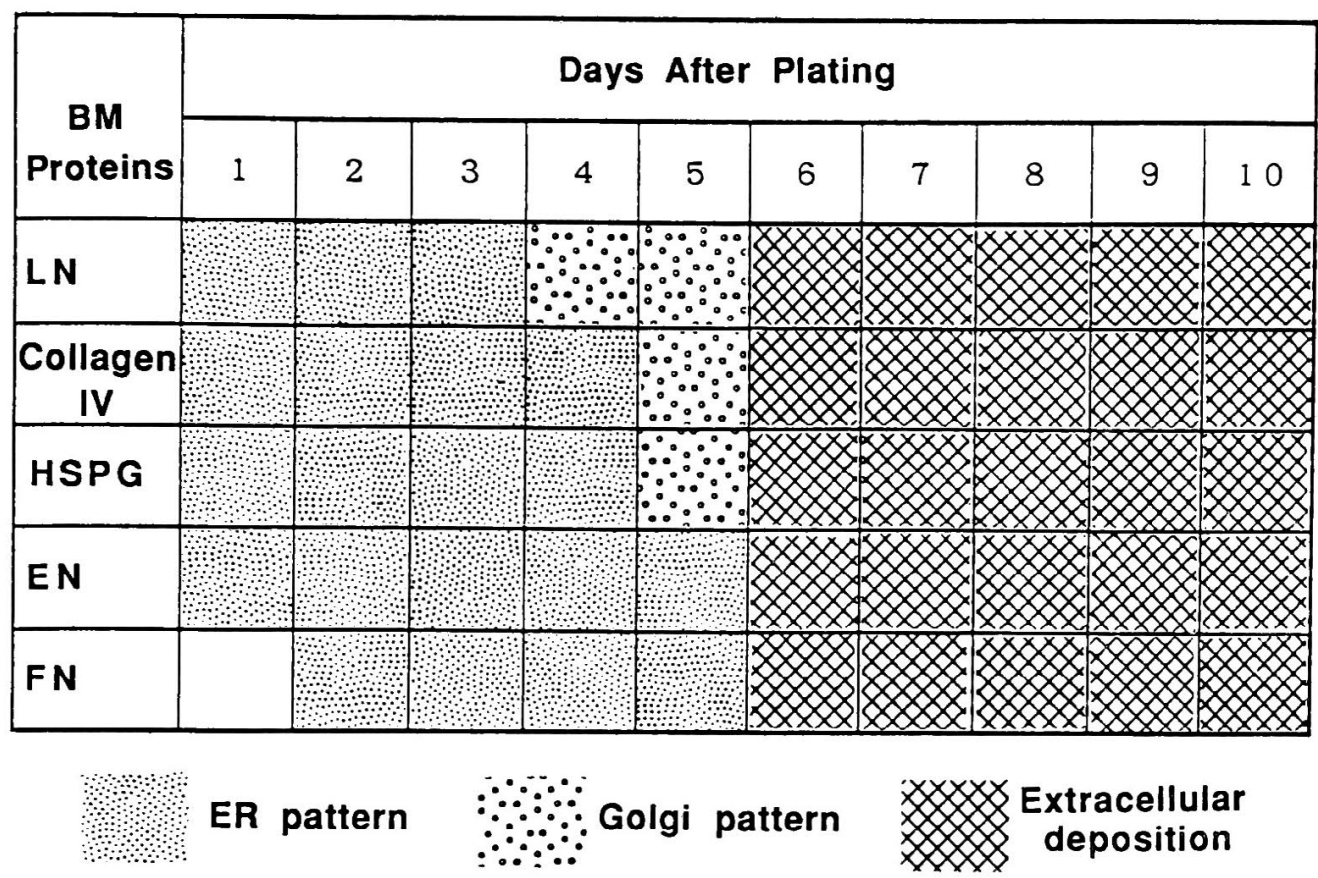

Fig. 17 Schematic time course of biosynthesis and secretion of basement membrae proteins by ACC cells : determination based on immunofluorescence patterns.

で内面をおおわれていることに，われわれは以前 より，注目していた ${ }^{12)}$ 。

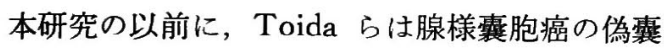
胞腔内に基底膜物質 $I$ 型コラゲン， ラミニンとフ アイブロネクチンが存在することを免疫組織化学 的に証明していた ${ }^{31,32)}$ 。さらに, Caselitz ら ${ }^{33)}$ Azumi \& Battifora ${ }^{34)}$ も同様の報告をしている。 しかし，かれらは，それらの報告で，抗体をもち いて, 偽䡒胞内に個々の基底膜分子を証明はした ものの，偽霝胞以外の腺様囊胞癌組織内に基底膜 物質がどのように分布し, この腫瘍の組織構築に いかなる影響をおよぼしているのか，また，それ らの基底膜分子の由来についての 問題意識はもっ ていなかった。

今回の研究で, 著者は, 四種類の基底膜分子の 腺様霖胞癌組織内における 免疫組織学的局在を, はじめて，広範囲に比較検討した。基底膜分子は， ひとり偽襄胞内にかぎらず，ひろく腫瘍間質に蓄 積されており，しかも，腺樣輁胞癌細胞がみずか らこの四種類の基底膜タンパク質を産生すること をみいだした。基底膜産生はこの腫瘍の基本的性
格であり，このことが基底膜の豊富な組織にこの んで浸潤したり，経過がゆるやかであるなどの特 異な臨床像を規定している可能性をしめした。

<偽軎胞と腫瘍間質 $>$

再度, 電子顕微鏡的所見について言及寸ると， 偽囊胞は多層の基底膜樣構造で裏うちされ，囊胞 腔には均質無構造な物質, 微細な線維状, あるい は，星状の顆粒性物質をいれており，まれに噖原 線維の断片が観察される ${ }^{7-12)}$ 。今回の 免疫組織化 学的染色では, 基底膜分子の陽性反応が偽囊胞辺 縁部だけでなく，腔内にびまん性であったが，こ のことは，電子顕微鏡的に認められる基底膜にく みこまれていないフリーな状態の分子が 需胞内に 多数存在していることをしめしている。囊胞腔に は，間質細胞がほとんどみられないので，これら の基底膜分子は偽霬胞周囲の腫瘍細胞によって 産 生されるのではないかと, 免疫染色の結果をえた 時点で，予想された。

基底膜タンパク質は，偽囊胞以外の閒質にも存 在していた。硝子様間質は, 電子顕微鏡的には均 質無構造または微細線維状で11)，免疫組織化学的 
反応様式は霟胞腔内と近似し，基底膜物質を主体 にした細胞外基質の沈着とおもわれる。これに対 して，疎性結合組織性の間質は，へパラン硫酸プ ロテオグリカンが主体で，このプロテオグリカン がほかの基底膜分子とことなる生合成の機序を持 つ可能性を示唆している。岡田らは巨大分子量で, 密度勾配遠心で低密度のへパラン硫酸糖鎖を有す るプロテオグリカンが培養間葉系細胞によって合 成されたことを報告している ${ }^{35)}$ 。興味あることに， そのプロテオグリカンは，成熟ラット間質にはみ られず，胎児の間質だけにみいだされている。

基底膜の免疫染色をおこなうと, 偽霊胞腔と外 側の硝子様間質とが連続していることが 明瞭に観 察された。この結果から，偽亯胞の形成過程はつ ぎのようにかんがえられる。1）腫瘍細胞の小胞 巣では, 個々の細胞が基底膜に接して配列し，2） 胞巣が索状にのびて多方向に生長するにしたが い，胞宩はたがいに融合しあって複雑に陥入した 間質を形成し，3）陥入した間質は，外側の間質か ら隔離され，4）隔離された間質，すなわち，偽露 胞は腫瘍細胞の分泌する基底膜物質を主体とした 細胞外基質の貯留によって扡張する。唐草模様の 間質は偽襄胞の逆の表現形である。5）もうひとつ の偽亭胞形成の経路として, 島嶼状の胞巣では, 腫瘍細胞が胞巣内の細胞間隙に細胞外基質を 分泌 し，偽亭胞となる間質をつくる。

ここで，注目すべきは，どのような組織型の腺 様襄胞癌でも, 腫瘍細胞が基底膜分子陽性の間質 に接しうるように配列していることである。唯一 の例外は, solid type with necrosis の組織型で あるが, しかし，この型の腫瘍胞巣にさえも，米 粒状基底膜陽性の間質が散在しており，後述する ように, 腺癌との鑑別診断を可能にしている。こ の組織型では, 基底膜物質の沈着と腫瘍細胞増殖 の速度が他組織型とことなり，胞巣の中心部に凝 固壊死をおこすことが推測される。これらの結果 より, 腺様襄胞癌細胞の増殖には, 基本的に基底 膜が必要であることが示唆された。

<腺様囊胞癌の基底膜親和性 $>$

基底膜の豊富な末梢神経，血管壁，骨格筋組織 への腺様囊胞癌細胞の侵襲は, 免疫染色によって, より明瞭に観察された。腺様霟胞癌の神経侵襲は,
従来の教科書では，神経周囲のリンパ管への浸潤 によると説明されていた ${ }^{38,37)}$ 。しかし，この解釈 では, この腫瘍のリンパ行性転移が比較的すくな く，長期間をへて，末梢神経にそった中枢神経系

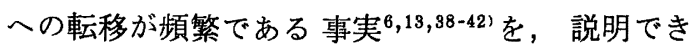
ない。H. E. 染色標本では, 神経周囲のリンパ管 腔の同定は困難であるが, 今回の基底膜免疫染色 によって，腫瘍細胞がリンパ管ではなくて，神経 内膜, 神経周膜を侵襲しているのがあきらかにで きた。著者はこの所見を腺様囊胞癌細胞が基底膜 の豊富な末梢神経に親和性をもつためと解釈して いる。同様に, 骨格筋, 血管侵襲の頻繁なこと, さらに血行性転移をおこしやすい傾向 ${ }^{6,14}{ }^{\prime}$ は，こ の腫瘍の基底膜親和性で説明できそうである。

腺椂囊胞癌の基底膜親和性という性格は, この 腫瘍の組織構造にのみならず, その生物学的性格 にも反映している。唾液腺の腺様囊胞癌は腺癌よ り予後がよいため, 低悪性度あるいは中悪性度の 腫瘍とみなされている象年,41-43)。しかし, solid type with necrosis の組織型は例外で, 予後は不 良である ${ }^{6,14,44,45)}$ 。これは，前述のとおり，この 型の腺様襄胞癌細胞が十分に基底膜と 接着すると いう性格をうしなったためかもしれない。

<腺様囊胞癌細胞の基底膜産生 $>$

腺様霆胞癌の特異な組織構築と臨床像とが 腫瘍 細胞の 基底膜好性で説明されそうであるとなれ ば， その基底膜が癌細胞自身から産生されるのか どうかに興味がもたれる。

Barsky らは, ELISA 法と SDS アクリルアミ ド電気泳動法をもちいて, ヌードマウスの腺様襄 胞癌と卵黄囊腫移植腫瘍組織から, ラミニンと $\mathrm{IV}$ 型コラゲンを証明して, 各腫瘍組織内で, 基底膜 物質が産生されていることを報告している ${ }^{46) 。}$ Sobue らは, われわれの ACC2, ACC3 類似の 腺様囊胞癌の株細胞を樹立し，基底膜物質陽性の 細胞外基質を免疫組織化学的にしめした ${ }^{47)}$ 。しか し，これらの実験は，腫瘍細胞自身による基底膜 合成を直接的に証明してはいなかった。

今回の, 七トの唾液腺腺様霆胞癌由来の株細胞 ACC2, ACC3 をもちいた実験では, 螢光抗体法 によって, 腺様霊胞癌細胞による基底膜分子の細 胞内生合成, 細胞外分泌の過程を詳細に追跡しえ 
た。ヌードマウス移植実験では， $\mathrm{ACC} 2, \mathrm{ACC} 3$ 細胞は，偽噻胞形成能を保持していることが証明 された。経時的な観察の結果, ACC2, ACC3 細 胞は，いずれも，四種類の基底膜タンパク質，IV 型コラゲン，ラミニン， ヘパラン硫酸プロテオグ リカン，エンタクチンとファイブロネクチンを生 合成することの直接的な証拠がえられた。その生 合成は，細胞内の小胞体パタン，ゴルジパタンで 確認されたし, 細胞外沈着からは, ACC $2, \mathrm{ACC} 3$ 細胞による，これらの物質の分泌が証明された。 寸なわち，腺様襄胞癌の 特徵的な 間質の大部分 は，腫瘍実質細胞によって形成されるといえるだ ろう。

小胞体ないしゴルジ装置での局在を 確定するに は，免疫電顕的証明が必要であることはいうをま たない。Ishimura らはラット腎メサンジウム細胞 を培養して，光顕レベルで細胞外基質の小胞体パ タン，ゴルジパタンの免疫染色の結果をえて，こ れらを, 電顕的に追認しているので ${ }^{48)}$, 著者は, 今回の実験結果の細胞内局在の 解釈に無理がある とはかんがえていない。

腺様車胞癌の間質には，炎症性細胞の反応がと ぽしいことにも，われわれは注目してきたが，こ の組織学的特徵と，実質細胞による活発な間質形 成とのあいだにはなんらかの 関係があるかもしれ ない。また, $\mathrm{ACC} 2, \mathrm{ACC} 3$ 細胞では,ゴルジパ タンや細胞外沈着の出現時期がタンパク質によっ てことなっており，それぞれのタンパク質の生合 成と分泌が独立した相を有することを示唆してい る。しかし，それらの「ずれ」の制御がどのよう な意義をもつのかは，今後解明すべき課題である。

今回もちいた ACC2, ACC3 の細胞系は, ヒ トの基底膜タンパク質産生細胞としてきわめて 貴 重であり, 今後, 細胞外基質の実験モデルとして, 基底膜構造の解明などにひろく利用されうるだろ う。また，ヒトの基底膜タンパク質の供給源とし ても重要なものであることを特記したい。

<基底膜分泌と細胞増殖>

基底膜は，前述のとおり，それに付着した上皮 細胞の形態, 生長, 分化に影響をおよぼすことが しられている ${ }^{499}$ 。

今回の実験では，まず， $\mathrm{ACC} 2, \mathrm{ACC} 3$ 細胞
は，ファイブロネクチンでコーティングしたフラ スコ上で，きわめてよく伸展することが観察され たが, 最近, Ingber は, 毛細血管内皮細胞で, 細 胞形態と増殖の関係に 関してコンピュータ画像解 析によって興味ある 報告をしている501。すなわ ち, 細胞投射面積は 接触ファイブロネクチン濃度 と DNA 合成量とに正比例するというもので, 細 胞外基質によって伸展した細胞の 細胞増殖活性が たかいという結果は興味ぶかい。

細胞が伸展するには，これにさきだって，細胞 が基質に付着することが 重要な条件であるとされ ているが51-53)，今回は，細胞の接着に関する実験 はおこなっていない。しかし，細胞膜上の細胞外 基質受容体には，インテグリンファミリーをはじ め，あらたに発見されるものも多く54)，ACC2， ACC3 細胞は, この方面の好研究材料として, 注 目されよう。

細胞増殖度測定の結果から, ACC2, ACC3 細 胞の増殖は，ファイブロネクチンによるコーティ ングによって，抒おき変化することがしめされ た。増殖曲線の多相性からは、コーティングにも ちいられたファイブロネクチン以外の, 細胞自身 から産生分泌される 基底膜分子やファイブロネク チンなどの 細胞外基質の影響が示唆された。すな わち, この腫瘍細胞には, 自己が分泌する細胞外 基質によって自己の増殖が 制御されるという autocrine 機構が存在するとかんがえられる。同様 の観察を, Ishimura らが培養ラット腎メサンジウ ム細胞についておこなっている ${ }^{481}$ 。かれらは，免 疫細胞化学的に, この細胞が, III型, およびIV型 コラゲン，ラミニンとファイブロネクチンを生合 成し，この細胞自身産生したIV型コラゲン，ラミ ニンの細胞外沈着が，そのほかの細胞外基質の生 合成を促進させ，また，細胞自身の増殖にも影響 することをしめした。上皮系細胞については, Madara らが，間質型コラゲンによって，ヒトの培養 腸上皮細胞の伸展, 集密化がうながされるという 報告をしている ${ }^{55)}$ 。

今回の実験結果から， $\mathrm{ACC} 2, \mathrm{ACC} 3$ 細胞で は，基底膜分子種によって，細胞内生合成と細胞 外沈着の多少と時間的ずれがあることがうかがわ れた。さまざまな種類の細胞が，培養の環境によ 
って, 細胞外基質の産生のパタンを変化させるよ うであることは, 前述の autocrine 機構を証明す るものである。ヒトの神経膠腫由来細胞培養産物 を分析した McKeever らによれば，同一腫瘍由 来でも, 細胞系によって, ラミニン, IV 型コラゲ ン，還元銀陽性コラゲンの生合成量がことなると いら ${ }^{56)}$ 。Rutka らは, ヒト悪性神経膠腫由来細胞 をラミニンとファイブロネクチンでコーティング した容器で培養すると, 細胞がよく増殖し, 敷石 状に集密化するのに, 正常軟膜の細胞外基質, す なわち，I 型およびIV型コラゲンでコーティング した場合, 細胞の増殖が低下し, 分化が誘導され て星状の形態を呈し, 異型性がたかまり，GFAP の産生が, 無コーティングより, 増加するという, 細胞外基質による腫瘍細胞分化制御の現象を 報告 している57。また, Erkell らは, マウスの転移性 リンパ腫細胞が，非転移性のリンパ腫細胞より， 基底膜物質を含むゲルに浸入しやすいという，細 胞側の事情によって細胞外基質との親和性に 相違 が生じることをみいだした ${ }^{58)}$ 。

以上のと㧍り，細胞外基質の分泌が，上皮系お よび非上皮系腫瘍細胞の増殖, 分化, 転移などに, 重要な現象であろうことはまちがいないが，細胞 一般に通用する原則をみいだすまえに，個々の種 類の細胞によってことなる現象のさらに詳細な観 察が必要であろう。

＜鑑別診断>

腺様囊胞癌の基底膜免疫染色パタンが複雑な 様 相を呈するのに対し，腺癌のそれは腫瘍胞巣周囲 においてのみ陽性という，きわめて単純なもので あった。したがって，H．E. 染色標本上では鑑別 の困難な組織型の腺様囊胞癌と腺癌の診断に, こ の免疫染色は有用であることが判明した。たとえ ば，篩状構造の不明瞭な solid type 腺様軍胞癌と solid type 腺癌の鑑別，小偽霆胞を有する tubular type 腺様露胞癌と tubular type 腺癌の鑑別など
である。前者の場合, 基底膜免疫染色で, 充実性 胞宩内に斑状の陽性所見があれば，腺様震胞癌と 診断される。後者の場合, 管腔様構造の腔内が陽 性であれば，腺様品胞癌が診断される。腺様露胞 癌の外科手術では，より広範囲な切除がおこなわ れるので, この鑑別診断の確立は臨床的に重要な 意味をむつ。

<ヒアルロニダーゼ処理 $>$

組織切片上での基底膜の免疫染色には，切片を ヒアルロニダーゼで前処理するのが必須である。 酵素処理による染色性の向上は，基底膜各分子と ヒアルロン酸の結合のあることを意味する。臓器, 組織部位による基底膜の異種性が 報告されている が59-61)，各組織で各抗体に対する酵素消化感度が 相違するという今回の結果は, 組織部位によって, 四種類の基底膜分子とヒアルロン酸との 結合様式 に特異性があることをしめしている。胎児組織で 報告されているように ${ }^{21,62,63)} ，$ ヒアルロニダーゼ 処理が細胞外基質タンパク質の 免疫組織化学的染 色の基本的な手順とかんがえられる。

謝辞：本研究をおこなうにあたって終始御魄篤なるご 指導と本論文のご校閲を賜りました岡適治男教授に心よ り感顔致します。

本研究の計画と実施には, 新潟大学歯学部の䍭 敬教 授に直接のご指導をいただきました。また, 上海第二医 科大学口腔医学院の劉㻴如教授より外科材料, 同医学 院の邱蔚六教授と何 栄根教授より株細胞を提供して いただき, 長崎大学歯学部の坂井英昭博士, 柴田恭明学 士には，各種タンパク質の精製と抗体作製でご援助をう けました。実験をすすめるにあたっては, 長崎大学歯学 部口腔病理学教室員各位のご助言とご協力をいただきま した。ここに,あつく御礼を申しあげます。

本論文の要旨は, 第77回おょび第79回日本病理学会総 会（1988年 6 月札幌，1990年 3 月福岡）と第 5 回国際口 腔病理学会（1990年 7 月東京）に拈いて発表した。

抄録: 腺様露胞癌の外科摘出材料をもちいて, 腫瘍組織内の四種類の基底膜タンパク質: IV 型コラゲン, ラ ミニン, ヘパラン硫酸プロテオグリカン, エンタクチンの局在を免疫組織化学的に検討した。基底膜タンパク 質は腺様震胞癌に特徵的な偽霟胞腔はじめ,ひろく腫瘍間質に蓄積していた。また，この腫瘍特有の神経， 笳肉，血管侵襲は腫瘍細胞の基底膜親和性によって説明できることが示唆された。そこで，ヒト唾液腺腺様銮 胞癌由来の株細胞 ACC2, ACC3 を用いて, 試験管内で基底膜タンパク質およびファイブロネクチンの生合 
成を螢光抗体法で追跡したところ，継代後，細胞が接着，伸展，増殖するのにともなって，細胞内の小胞体 や, ゴルジ装置での局在を示唆する所見や, 細胞外沈着がみとめられた。すなわち, 腺様豪胞癌実質細胞は四 種類の基底膜分子とファイブロネクチンを産生し，細胞外に分必することが証明された。したがって，基底膜 生合成能が本腫瘍の組織構築と生物学的性格に反映されているとかんがえられた。

\section{文 献}

1) Hübner, G., Kleinsasser, O. und Klein, H. : Zur Feinstruktur und Genese der Cylindrome der Speicheldrüsen. Virchows Arch. [Pathol. Anat.] 347 : 296-315, 1969.

2) Thackray, A. C. and Lucas, R. B. : Tumor of the major salivary glands. The Armed Forces Institute of Pathology, Washington D. C., pp. 91-99, 1974.

3) Busuttil, A.: Adenoid cystic carcinoma of the minor salivary glands. J. Laryngol. Otol. $91: 41-53,1977$.

4) Nochomovitz, L. E. and Kahn L. B.: Adenoid cystic carcinoma of the salivary gland and its histologic variants. Oral Surg. 44 : 394-404, 1977.

5) Saku, T., Okabe, H., Yagi, Y., Sato, E. and Tsuda, N. : A comparative study on the immunolocalization of keratin and myosin in salivary gland tumors. Acta Pathol. Jpn. 34 : 1031-1040, 1984.

6) Cheng, J., Liu, A. R. and Liu, Z. : A clinicopathological study of 225 cases of adenoid cystic carcinoma of salivary glands. Chin. J. Stomatol. 20 : 15-18, 1985.

7) Hoshino, M. and Yamamoto, I. : Ultrastructure of adenoid cystic carcinoma. Cancer 25 : 186-198, 1970.

8) Tandler, B.: Ultrastructure of adenoid cystic carcinoma of salivary gland origin. Lab. Invest. 24 : 504-512, 1971.

9) Chisholm, D. M., Waterhouse, J. P., Kraucunas, E. and Sciubba, J. J.: A qualitative and quantitative electron microscopic study of the structure of the adenoid cystic carcinoma of human minor salivary glands. J. Oral Pathol. 4 : 103-119, 1975.

10) Chen, S. Y.: Adenoid cystic carcinoma of minor salivary gland. Histochemical and electron microscopic studies of cystlike spaces. Oral Surg. $42: 606-619,1976$.

11) Osborn, D. A.: Morphology and the natural history of cribriform adenocarcinoma (adenoid cystic carcinoma), J. Clin. Pathol. 30 : 195-205, 1977.

12) Cheng, J., Liu, A. R. and Liu, Z.: Electron microscopic and histochemical study of adenoid cystic carcinoma of salivary gland.
Chin. J. Stomatol. 20 : 135-137, 1985.

13) Tarpley, T. M. Jr. and Giansanti, J. S. : Adenoid cystic carcinoma. Analysis of fifty oral cases. Oral Surg. 41 : 484-497, 1976.

14) Perzin, K. H., Gullane, P. and Clairmont, A. C. : Adenoid cystic carcinoma arising in salivary glands: A correlation of histologic features and clinic course. Cancer $42: 265$ 282, 1978.

15) Thackray, A. C.: Histological typing of salivary gland tumours. World Health Organization Geneva, pp. 24-25, 1972.

16) Kühn, K., Wiedemann, H., Timpl, R., Risteli, J., Dieringer, H., Voss, T. and Glanville, R. W.: Macromolecular structure of basement membrane collagens. Identification of $7 \mathrm{~S}$ collagen as a crosslinking domain of type IV collagen. FEBS Lett. 125 : 123-128, 1981.

17) Risteli, L. and Timpl, R.: Isolation and characterization of pepsin fragments of la. minin from human placental and renal basement membranes. Biochem. J. 193 : 749-755, 1981.

18) Saku, T. and Furthmayr, H.: Characterization of the major heparan sulfate proteoglycan secreted by bovine aortic endothelial cells in culture: Homology to the large molecular weight molecule of basement membrane. J. Biol. Chem. 265 : 3514-3523, 1989.

19) Lwebuga-Mukasa, J. S., Saku, T., Foellmer, H. G. and Madri, J. A.: Adult rat type II pneumocytes secrete extracellular matrix components which regulate cell function. J. Cell Physiol. (in press)

20) Furthmayr, H.: Immunization procedures, isolation by affinity chromatography, and serological and immunochemical characterization of collagen specific antibodies, immunochemistry of the Extracellular Matrix. Volume I . (Edited by H. Furthmayr) CRC Press, Boca. Raton, pp. 143-178, 1981.

21) Sternberger, L. A., Hardy, P. H. Jr., Cuculis, J. J. and Meyer, H. G.: The unlabeled antibody enzyme method of immunohistochemistry : preparation and properties of soluble antigen-antibody complex (horseradish peroxidase-antihorseradish peroxidase) 
and its use in identification of spirochetes. $\mathrm{J}$. Histochem. Cytochem. 18 : 315-333, 1970.

22) Leivo, I., Vaheri, A., Timpl, R. and Wartiovaara, J. : Appearance and distribution of collagens and laminin in the early mouse embryo. Develop. Biol. 76 : 100-114, 1980.

23) He, R. G., Zhang, X. S., Zhou, X. J., Wang, Z., Zhang, X. L., Qiu, W. L., Han, Y. S. and Zhang, R. X.: The establishment of cell lines of adenoid cystic carcinoma of human salivary glands (ACC-2, ACC-3) and a study of morphology. West Chin. J. Stomatol. $6: 1-4,1988$.

24) Katsuta, H., Takaoka, T., Oishi, Y., Baba, T. and Chang, K. C.: Cultivation of fibroblasts form chick embryo heart in the sim. plified replicate tissue culture. Jpn. J. Exp. Med. 24 : 125-139, 1954.

25) Engvall, E. and Ruoslahti, E.: Binding of soluble from of fibroblast surface protein, fibronectin, to collagen. Int. J. Cancer 20 : 1-5, 1977.

26) Kefalides, N. A. : Structure and biosynthesis of basement membranes. Int. Rev. Connect. Tissue Res. 6 : 63-104, 1973.

27) Timpl, R., Rohde, H., Gehron-Robey, P., Rennard, S. I., Foidart, J. M. and Martin, G. R. : Laminin-A glycoprotein from basement membranes. J. Biol. Chem. 254 : 9933-9937, 1979.

28) Kanwar, Y. and Farquhar, M. C. : Isolation of glycosaminoglycans (heparan sulfate) from glomerular basement membranes. Proc. Natl. Acad. Sci. U. S. A. 76 : 4493-4497, 1979.

29) Carlin, B., Jaffe, R., Bender, B. and Chung, A. E. : Entactin, a novel basal lamina-associated sulfated glycoprotein. J. Biol. Chem. 256 : 5209-5214, 1981.

30) Mazur, M. T. and Battifora, H. A.: Adenoid cystic carcinoma of the uterine cervix : Ultrastructure, immunofluorescence, and criteria for diagnosis. Am. J. Clin. Pathol. 77 : 494-500, 1982.

31) Toida, M., Takeuchi, J., Hara, K., Sobue, M., Tsukidate, K., Goto, K. and Nakashima, N.: Histochemical studies of intercellular components of salivary gland tumors with special reference to glycosaminoglycan, laminin and vascular elements. Virchows Arch. [Pathol. Anat.] 403 : 15-26, 1984.

32) Toida, M., Takeuchi, J., Sobue, M., Tsukidate, K., Akao, S., Fukatsu, T. and Nakashima, N.: Histochemical studies on pseudocysts in adenoid cystic carcinoma of the huma salivary gland. Histochem. J. 17 : 913-924, 1985.
33) Caselitz, J., Schulze, I. and Seifert, G. : Adenoid cystic carcinoma of the salivary glands: an immunohistochemical study. J. Oral Pathol. 15 : 308-318, 1986.

34) Azumi, N. and Battifora, H.: The cellular composition of adenoid cystic carcinoma. An immunohistochemical study. Cancer 60 : 1589-1598, 1987.

35）岡田貫子，加藤正人，鈴木 旺，木全弘治 : 基 底膜成分, 低密度へパラン硫酸プロテオグリカ ンの間充織による合成. 第41回日本細胞生物学 会大会講演要旨集 pp. 89, 1988.

36) Bhaskar, S. N.: Synopsis of Oral Pathology, Fifth Edition. The C. V. Mosby Com. pany, St. Louis, pp. 578, 1977.

37) Anderson, W. A. D. and Kissane, J. M. : Pathology, Seventh Edition. The C. V. Mosby Company, St. Louis. pp. 1276, 1977.

38) Foote, F. W. Jr. and Frazell, E. L. : Tumors of the major and minor salivary glands. Cancer $6:$ 1065-1133, 1953.

39) Leafstedt, S. W., Gaeta, J. F., Sako, T., Marchetta, F. C. and Shedd, D. P.: Adenoid cystic carcinoma of major and minor salivary glands. Am. J. Surg. 122 : 756-762, 1971.

40) Conley, J., Myers, E. and Cole, R. : Analysis of 115 patients with tumors of the submandibular gland. Ann. Otol. Rhinol. Laryngol. 80 : 323-330, 1972.

41) Seaver, P. R. and Kuhn, P. G.: Adenoid cystic carcinoma of salivary glands: A study of ninety-three cases. Am. J. Surg. $137: 449-$ 455, 1979.

42) Spiro, R. H., Huvos, A. G. and Strong, E. W.: Adenoid cystic carcinoma: Factors influencing survival. Am. J. Surg. $138: 579$ 583, 1979.

43) Man, D. and McInnes, G.: Adenoid cystic carcinoma of minor salivary glands. Dela. ware Med. J. 52 : 423-425, 1980.

44) Marsh, W. L. and Allen, M. S. : Adenoid cystic carcinoma: Biologic behavior in 38 patients. Cancer 43 : 1463-1473, 1979.

45) Szanto, P. A., Luna, M. A., Tortoledo, M. E. and White, R. A.: Histologic grading of adenoid cystic carcinoma of the salivary glands. Cancer 54 : 1062-1069, 1984.

46) Barsky, S. H., Layfield, L., Varki, N. and Bhuta, S.: Two human tumors with high basement membrane-producing potential. Cancer 61 : 1798-1806, 1988.

47) Sobue, M., Takeuchi, J., Niwa, M., Yasui, C., Nakagaki, S., Nagasaka, T., Fukatsu, T., Saga, S. and Nakashima, N. : Establishment of a cell line producing basement 
membrane components from an adenoid cystic carcinoma of the humans alivary gland. Virchows Arch. [Cell Pahol.] 57 : 203-208, 1989.

48) Ishimura, E., Sterzel, R. B., Budde, K. and Kashgarian, M.: Formation of extracellular matrix by cultured rat mesangial cells. Am. J. Pathol. 134 : 843-855, 1989.

49) Timpl, R. and Dziadek, M. : Structure and biological activity of basement membrane proteins. Eur. J. Biochem. $180: 487-502$, 1989.

50) Ingber, D. E. : Fibronectin controls capil. lary endothelial cell growth by modulating cell shape. Cell Biol. $87: 3579-3583,1990$.

51) Campbell, J. H. and Terranova, V. P. : Laminin: molecular organization and biological function. J. Oral Pathol. 17 : 309323, 1988.

52) Aumailley, M. and Timpl, R. : Attachment of cells to basement membrane collagen type IV. J. Cell Biol. 103 : 1569-1575, 1986.

53) Tomaselli, K. J., Damsky, C. H. and Reichardt, L. F.: Interactions of a neuronal cell line (PC12) with laminin, collagen IV, and fibronectin: Identification of integrinrelated glycoproteins involved in attachment and process outgrowth. J. Cell Biol. 105 : 2347-2358, 1987.

54) Hynes, R. O.: Integrins : a family of cell surface receptors. Cell $48: 549-554,1987$.

55) Madara, J. L., Stafford, J., Dharmsathaphorn, K. and Carlson, S. : Structural analysis of a human intestinal epithelial cell line. Gastroenterology 92 : 1133-1145, 1987.

56) McKeever, P. E., Fligiel, S. E. G., Varani, J., Castle, R. L. and Hood, T. W. : Products of cells cultured from gliomas VII. Extracellular matrix proteins of gliomas which contain glial fibrillary acidic protein. Lab. Invest. 60 : 286-295, 1989.

57) Rutka, J. T., Giblin, J. R., Apodaca, G., DeArmond, S. J., Stern, R. and Rosenblum, M. L. : Inhibition of growth and differentiation in a malignant human glioma cell line by normal leptomeningeal extracellular matrix proteins. Cancer Res. $47: 3515-3522$, 1987.

58) Erkell, L. J. and Schirrmacher, V.: Quantitative in vitro assay for tumor cell invasion through extracellular matrix or into protein gels. Cancer Res. 48 : 6933-6937, 1988.

59) Martinez-Hernandez, A. and Amenta, P. S. : The basement membrane in pathology. Lab. Invest. $48: 656-677,1983$.

60) Kefalides, N. A., Howard, P. and Ohno, N. : Heterogeneity in basement membranes determines their structure and function, Basement Membrane. (Edited by Shibata S.) Elsevier Science Publishers B. V, Amsterdam, pp 73-87, 1985.

61) Couchman, J. R.: Heterogeneous distribution of a basement membrane heparan sulfate proteoglycan in rat tissues. J. Cell Biol. 105 : 1901-1916, 1987.

62) von der Mark, H., von der Mark, K. and Gay, S. : Study of differential collagen synthesis during development of the chick embryo by immunofluorescence. I . Preparation of collagen type I and II specific antibodies and their application to early stages of the chick embryo. Develop. Biol. 48 : 237-249, 1976.

63) Vertel, B. M. and Dorfman, A.: An immunohistochemical study of extracellular matrix formation during chondrogenesis. Develop. Biol. 62 : 1-12, 1978. 